NBER WORKING PAPER SERIES

NETWORKED FDI: SALES AND SOURCING PATTERNS OF JAPANESE FOREIGN AFFILIATES

Richard Baldwin

Toshihiro Okubo

Working Paper 18083

http://www.nber.org/papers/w18083

\author{
NATIONAL BUREAU OF ECONOMIC RESEARCH \\ 1050 Massachusetts Avenue \\ Cambridge, MA 02138
}

May 2012

Toshihiro Okubo received support for this research from REITI, a research institute associated with the Ministery of Economy, Trade and Industry. The views expressed herein are those of the authors and do not necessarily reflect the views of the National Bureau of Economic Research.

NBER working papers are circulated for discussion and comment purposes. They have not been peerreviewed or been subject to the review by the NBER Board of Directors that accompanies official NBER publications.

(C) 2012 by Richard Baldwin and Toshihiro Okubo. All rights reserved. Short sections of text, not to exceed two paragraphs, may be quoted without explicit permission provided that full credit, including (C) notice, is given to the source. 
Networked FDI: Sales and Sourcing Patterns of Japanese Foreign Affiliates

Richard Baldwin and Toshihiro Okubo

NBER Working Paper No. 18083

May 2012, Revised June, 2012, Revised July 2013

JEL No. F21,F23

\begin{abstract}
$\underline{\text { ABSTRACT }}$
This paper applies a novel empirical approach to characterising the horizontal-ness and vertical-ness of affiliates based on Yeaple's complex FDI concept. In its simplest form, horizontal-ness is measured as affiliates' local sales share while their vertical-ness is measures as their share of non-local sourcing of intermediates. Japanese affiliates in most sectors and nations are partly vertical and partly horizontal but those in North American are far more 'horizontal' than those in the EU and Asia. Affiliates became more vertical between 1996 and 2005. A four-way sales and sourcing split (host, home, regional and RoW) suggests that affiliates act as nodes in regional production networks - especially in Asia. We posit several hypotheses that could be tested with our empirical approach.
\end{abstract}

\author{
Richard Baldwin \\ Cigale 2 \\ 1010 Lausanne \\ SWITZERLAND \\ and CEPR \\ and also NBER \\ rbaldwin@cepr.org \\ Toshihiro Okubo \\ Keio University \\ 2-15-45 Mita Minato-ku \\ Tokyo Japan \\ okubo@econ.keio.ac.jp \\ okubo@econ.keio.ac.jp
}




\title{
Networked FDI: Sales and sourcing patterns of Japanese foreign affiliates
}

\author{
Richard Baldwin $^{1}$ and Toshihiro Okubo ${ }^{2}$ \\ Graduate Institute, Geneva and University of Oxford; Keio University \\ This version: May 2013; first draft: January 2012
}

\begin{abstract}
This paper applies a novel empirical approach to characterising the horizontal-ness and vertical-ness of affiliates based on Yeaple's complex FDI concept. In its simplest form, horizontal-ness is measured as affiliates' local sales share while their vertical-ness is measures as their share of non-local sourcing of intermediates. Japanese affiliates in most sectors and nations are partly vertical and partly horizontal but those in North American are far more 'horizontal' than those in the EU and Asia. Affiliates became more vertical between 1996 and 2005. A four-way sales and sourcing split (host, home, regional and RoW) suggests that affiliates act as nodes in regional production networks - especially in Asia. We posit several hypotheses that could be tested with our empirical approach.
\end{abstract}

Keywords: Vertical and horizontal FDI, complex FDI, Networked FDI, sourcing, sales, Japanese foreign affiliates, Multinationals

JEL classification: F21, F23

\section{Introduction}

The theory of multinational corporations answers two questions: Why is production multinational, and why is it owned by one corporation? Canonical foreign direct investment (FDI) theory concentrates on the first question and proposes two answers that define two types of FDI: horizontal (Markusen, 1984) and vertical (Helpman, 1984). The former has production being multinational to avoid trade costs ('market seeking'); the latter has production stages dispersed to exploit cost differences ('efficiency seeking'). See Antras and Yeaple (2013) for a survey. The relative importance of the two motives is an empirical question whose answer has evolved. The first modern tests identified motives by correlating measures of FDI with host-nation size (market seeking) and host-home nation costs differences (efficiency seeking). These studies find horizontal motives to be dominant (Carr, Markusen and Maskus 2001, Blonigen, Davies and Head 2003, and Markusen and Maskus 2002). See Blonigen (2005) and Navaretti and Venables (2004) for surveys.

More recent empirical work reveals difficulties with the two-way division. One set of studies uses the characteristics of parent-affiliate pairs to identify motives. Feinberg and Keane (2006) - looking at trade - and Alfaro and Charlton (2009) - looking at production - find that few parent-affiliate pairs fit neatly into the horizontal or vertical categories. Hanson, Mataloni and Slaughter $(2001,2005)$ document three additional types of FDI where affiliates: (i) produce for export to third markets (export platform FDI), (ii) add value to inputs sourced

\footnotetext{
${ }^{1}$ Graduate Institute, Geneva and University of Oxford,.rbaldwin@ @eepr.org; We thank Gordon Hanson, Andy Bernard, Beata Javorcik, Kalina Manova, Nicolas Berman, and Peter Egger for constructive and incisive comments that have improved the paper. The access to micro-data was arranged by RIETI. This research was partly financed by Grant-in-Aid for Scientific Research (Grant Number 21730194).

${ }^{2}$ Faculty of Economics, Keio University. okubo@econ.keio.ac.jp 2-15-45 Mita Minato-ku Tokyo Japan
} 
from their parents, or (iii) act as wholesale distributors. Yeaple (2003a, b) finds many affiliates with mixed motives and places them in a catch-all category called 'complex FDI'. 3 Ekholm, Forslid and Markusen (2007) document the importance of 'export-platform FDI'. Arnold and Javorcik (2009) show that foreign-ownership makes plants both less horizontal (more export oriented) and more vertical.

The principle contributions of our paper are threefold. First, using Japanese-affiliate data for all sectors and all nations, we confirm the shortcomings of the horizontal-versus-vertical distinction. Second, we apply a novel empirical approach to characterising the horizontalness and vertical-ness of affiliates. Our method focuses on the trade behaviour of affiliates rather than on parent-affiliate characteristics, or affiliates sales; it is best thought of as an empirical implementation of Yeaple's complex FDI concept.

In its simplest form, our method plots each affiliate in a 'sales-sourcing box' that has the share of local sales on the y-axis and the share of local sourcing of intermediates on the $\mathrm{x}$ axis. We associate low levels of local sourcing with vertical motives. When affiliates import intermediates for further processing, it is likely that the further processing is cheaper in the host nation but the intermediates are cheaper abroad - a clear indication that the affiliate's location is at least in part motivated by efficiency seeking. Following this logic, we define an affiliate's vertical-ness as its non-local-sourcing share. By contrast, we associate high levels of local sales with horizontal-ness; if most output is sold locally then market-seeking was probably an important motive. We define an affiliate's horizontal-ness as its local-sales share. In this way, each affiliate is associated with a measure of vertical-ness and a measure of horizontal-ness.

Using this perspective, we establish: (i) Japanese FDI in almost all sectors and almost all nations involves some 'vertical-ness', and some 'horizontal-ness'; (ii) North American affiliates are far more 'horizontal' than those in Asia and Europe; and (iii) between 1996 and 2005 affiliates became more vertical in most nations and sectors. Moreover, using a four-way sales-and-sourcing split (host-nation, home-nation, other nations in the region and rest-ofworld) we find a pattern that suggests many affiliates are part of international production networks - especially in Asia. We call this 'networked FDI' to shift the emphasis from the characteristics of individual affiliates and parent-affiliate-pairs to interactions among affiliates.

One implication of networked FDI is the notion of 'regional comparative advantage.' That is, the FDI-attractiveness of one host nation may be boosted by the existence of related affiliates in the region - with both sales and sourcing mattering (FDI equivalent of backward and forward linkages). We conjecture that such considerations could be important in informing developing nations' industrialisation policy. For example, it suggests that Vietnam's experience with FDI and international supply chains may have little relevance to, say, Uruguay's FDI prospects since Vietnam is in the midst of a dense FDI network while Uruguay is not. Such third-nation effects have been explored and documented (Baltagi, Egger and Pfaffermayr 2005, Blonigen, Davies, Waddell and Naughton 2007, Garretsen and Peeters, 2009) but only on the sales side (backward linkages). ${ }^{4}$ Third-nation effects on the sourcing side (forward linkages) may also be in operation and are likely to be especially important in sectors where production unbundling is particularly important. These have not, to our knowledge, been explored empirically.

\footnotetext{
${ }^{3}$ Important syntheses and theoretical extensions of Yeaple's distinctions include Ekholm, Forslid and Markusen (2007), Grossman, Helpman and Szeidle (2003), and Egger, Larch and Pfaffermayr (2004).

${ }^{4}$ See also Coughlin and Segev (2007) for spatial econometric analysis.
} 
The third contribution of our paper is to suggest how our continuous measures of horizontalness and vertical-ness could be used to test various hypotheses in the FDI literature. The rest of the introduction reviews the relevant literature in more detail.

\subsection{FDI literature and our paper}

The first empirical tests of FDI motives were based on the intuitive observation that trade and FDI should be complements under vertical motives but substitutes under horizontal motives. Most studies found them to be complements (e.g. Lipsey and Weiss 1981, Clausing 2000). The first modern evidence for horizontal motives came with the testing of the proximityversus-scale hypothesis. Brainard (1997) found that higher trade costs induced firms to sacrifice scale economies (splitting up production) in exchange for greater proximity to customers. The first theory-based tests that allowed for both motives came by considering whether FDI activity was greatest between big nations (market seeking), or between nations with big differences in endowments and/or factor prices (efficiency seeking). Here the main papers are Carr, Markusen and Maskus (2001), Blonigen (2001), Blonigen, Davies and Head (2003), Yeaple (2003b), Markusen and Maskus (2002), Helpman, Melitz, and Yeaple (2004), Davies (2008), and Braconier, Norbäck, and Urban (2005). Most studies using this identification strategy found horizontal to be the dominant motive.

As mentioned above, more recent studies tend to find evidence that the vertical motive is present in most cases so the two-way classification is inadequate. One important paper that uses trade data to investigate the horizontal versus vertical issues is Feinberg and Keane (2006). The authors focus on US-Canada parent-affiliate trade. They show that few parentaffiliate trade patterns correspond to pure horizontal or pure vertical motives with most reflecting mixed motives. One paper that is close to ours in its use of firm-level data and its focus on production networks is Antras and Foley (2009). Using US data, these authors examine the impact of the Asian Free Trade Agreement (AFTA) on US affiliates in the region. They find that AFTA raised the number and size of affiliates in the area compared to other Asian host nations. They also found that the share of sales to third nations (i.e. not the home or host nation) rose with AFTA, suggesting it fostered network-like integration rather than just host-home linkages. While this focus on the sales pattern of affiliates is similar to ours, the authors do not present information on the sourcing patterns as we do.

Arnold and Javorcik (2009) is also related as it shows how horizontal-ness and vertical-ness are changed when an Indonesian plant is acquired by a foreign owner. Their main finding is that foreign ownership boosts local-plant productivity. They suggest that one channel for such improvement is the reduction in horizontal-ness and increase in vertical-ness. Another paper that looks at production network aspects of FDI using firm level data is Alfaro and Charlton (2009). Their focus differs from ours in its use of parent-affiliate production classification rather than sales and sourcing data. The authors use Standard Industrial Classification (SIC) codes reported for each affiliate and its parent to classify each affiliateparent pair as horizontal, vertical or complex. Firms report up to six SIC categories for each entity. If the parent-affiliate pair shares any code, the authors call it horizontal FDI. If the affiliate has a code that is an input into one of the parent's codes, it is vertical FDI (an inputoutput table is used to determine inputs). If the pair meets both criteria, they call it complex FDI. The authors do not question the three-way classification of FDI. Their main finding like Hanson, Mataloni and Slaughter (2001) - is that earlier studies have misclassified much vertical FDI as horizontal. 
Our paper focuses on the trade behaviour of Japanese foreign affiliates. ${ }^{5}$ Other papers also focus on affiliates' trade but use US data which include information that is more limited. For instance, Hanson, Mataloni and Slaughter (2005) study affiliates' imports from US parents but remark: "our data are not well suited to examine production networks in their entirety." These authors find trade costs and wage differences are important determinants of parentaffiliate trade. Bernard, Jensen and Schott (2005) present evidence of US parent's trade with their affiliates in the context of a broad portrait of US exports and imports at the firm level, but they focus only on parent-affiliate sales and sourcing. Borga and Zeile (2004) study the US parent's intermediate exports to their affiliates. Our work looks at broader indicators of affiliate sales and sourcing.

A separate literature, which is not usually viewed as part of the FDI literature but which does speak to production networks, focuses on fragmentation as measured by trade in parts and components (Kimura and Ando, 2005; Athukorala and Yamashita, 2006; Athukorala, 2012). In line with these studies, we confirm that Asian fragmentation is mainly present in the electrical and mechanical machinery sectors. ${ }^{6}$

Finally our paper has some qualifications which we leave for future research. One important missing point concerns FDI's impact on the local economy. Using micro-data, the spillover impact of FDI on local economy is investigated by Barrios, Görg and Strobl (2005), Javorcik and Spatareanu (2008), Arnold and Javorcik (2009), and Javorcik (2004). ${ }^{7}$ Another important missing aspect in our investigation is consideration of firm heterogeneity, especially the link between sales-and-sourcing patterns and firm size. ${ }^{8}$

\subsection{Plan of paper}

Section 2 presents a brief overview of mainstream FDI theories and proposes a new diagram for organising thinking about FDI categories. We also show how the diagram can be used to organise thinking about the classic substitute-or-complement view of trade and FDI, and about development-linked FDI policies. The next section, Section 3, presents data on Japanese affiliates' sales and sourcing patterns using a two-way (local-versus-non-local) division of sales and sourcing patterns. Section 4 looks at four-way sale-and-sourcing patterns. Here the main result is that most FDI is networked regionally rather than globally. Section 5 discusses testable empirical hypotheses. Section 6 presents our concluding remarks.

\section{Analytic framework}

Foundational thinking about FDI was shaped by two-nation models that excluded intermediate goods (Helpman 1984, and Markusen 1984). ${ }^{9}$ This was natural since the theory arose just before the massive transformation of production known the second unbundling

\footnotetext{
${ }^{5}$ In terms of Japanese manufacturing FDI, Head et al. (1995) investigate location choice and agglomeration effects. See also Head and Ries (2003, 2005) on Japanese FDI determinants.

${ }^{6}$ Kimura and Ando (2005) and Athukorala and Yamashita (2006) use product-level SITC trade data to estimate the determinants of trade in parts and components in machinery sectors using the gravity equation and find evidence of substantial fragmentation and production networks in Asia. Jones, Kierzkowski and Lurong (2005), Athukorala (2012) and Kimura, Takahashi and Hayakawa (2007) provide related evidence. An early influential paper in this line of work is $\mathrm{Ng}$ and Yeats (2003).

${ }^{7}$ Görg and Strobl (2001 and 2002), using Irish micro-data, show that the presence of FDI has life-enhancing effect on local firms in high-tech industries. See Girma et al. (2001, 2002) and Girma and Wakelin (2001) for similar results in UK data.

${ }^{8}$ For surveys of literature on firm heterogeneity in export and FDI, see Greenaway and Kneller (2007) and Wagner (2007).

${ }^{9}$ See Helpman and Krugman (1985) Chapter 12 and 13, or Feenstra (2004) Chapter 11.
} 
(Baldwin 2006). This transformation has changed the motives behind and nature of FDI, but before turning to these new developments, we present a thumbnail sketch of the 1980s FDI theory.

The canonical model works with two nations, no intermediate goods, and a market structure with no multi-market effects. In this setting, a firm may find it advantageous to produce abroad for only two reasons: lower trade costs, and/or lower production costs. ${ }^{10}$ By satisfying each market from a local factory, horizontal FDI avoids trade costs, so FDI is a substitute for trade. Vertical FDI in its purest form involves final good production with value added in both nations, but goods production in only one. In Helpman (1984), for example, skill-intensive 'headquarter services' are undertaken in the home country while physical production occurs in the host country. Here FDI and trade in goods (and invisibles) are complements.

As trade and investment became increasingly entwined in the late $20^{\text {th }}$ century, theory evolved to account for the changes. The seminal paper by Yeaple (2003a) stepped beyond the horizontal-or-vertical paradigm. In a simple three-nation model, he studied 'complex' FDI strategies, i.e. individual firms engaging simultaneously in horizontal and vertical FDI. He elucidated how a firm's investments in various host nations can be complements or substitutes, and how trade and FDI may act as complements or substitutes. Ekholm, Forslid and Markusen (2007), and Grossman, Helpman and Szeidle (2006) generalised and confirmed Yeaple's results in richer models. ${ }^{11}$ The papers from the 2000s allow for third countries and thus opened the door to third-nation effects - i.e. locational choices influenced by something other than home and host nation factors. Baltagi, Egger and Pfaffermayr (2005) provided clear empirical evidence that third-country effects are important. Following development of the 'new new trade theory' (Melitz 2003), Helpman, Melitz and Yeaple (2004) introduced firm heterogeneity that allows for the co-existing of multiple forms of FDI.

\subsection{Classifying FDI by trade flows: The sales-sourcing box}

The modest empirical innovation in our paper is to classify affiliates according to their trade behaviour. Given the complexity of modern international supply chains, especially in East Asia, we believe that it is increasingly difficult to determine why a particular plant is set up abroad rather than at home. For example, in a world where final goods involve many inputs and intermediate good producers sell to each other, the efficiency-seeking and marketseeking dichotomy is blurred. Plants producing intermediates may locate near other intermediate producers both to be near their suppliers (efficiency seeking) and to be near their customers (market seeking) a la Krugman and Venables (1995). By focusing on the import and export behaviour of Japanese affiliates, we admit both motives matter and measures of both for each affiliate. We do not develop a formal model as it would be a simple extension of existing work. ${ }^{12}$

The two dimensions are shown in the sales-sourcing box (Figure 1); the canonical form show up on the edges. ${ }^{13}$

\footnotetext{
${ }^{10}$ For FDI motivated by strategic reasons rather than costs, see Baldwin and Ottaviano (2001).

${ }^{11}$ The first draft of Yeaple (2003a) was submitted to the Journal of International Economics in 2001; the first drafts of Ekholm, Forslid and Markusen (2007) and Grossman, Helpman and Szeidle (2006) came in 2003.

${ }^{12}$ A conceptually straightforward generalisation of Yeaple (2003a) - for example a many-nation version of Grossman, Helpman and Szeidle (2006) - would permit a much more complex range of FDI and trade outcomes. In such a model, we can envision foreign affiliates engaging in local and export sales as well as local and import sourcing of intermediate inputs.

${ }^{13}$ Also see Ando and Kimura (2005) which suggest a different two-dimensional classification with the axes being physical distance of the affiliate from the headquarters and tightness of corporate control over the affiliate.
} 
- Pure horizontal FDI is the northeast corner; affiliates sell all output locally and source all intermediates locally (in the early 1980s theory, intermediates were ignored by implicitly bundling them into the production function).

- Pure vertical FDI (Helpman 1984) is the western border since all intermediates (headquarter services) are sourced from abroad, but some of the final good output is exported back to the home nation.

- Pure export-platform FDI (i.e. outward processing) is the southwest corner; all intermediates are imported and all output is exported.

- Tariff-jumping assembly FDI (e.g. assembly of final autos from kits) is the northwest corner since all intermediates are imported and all output is sold locally.

The last corner represents pure resource extraction (cash-crop agriculture, mining, fishing, etc.) where all intermediate inputs (if any) are sourced locally and all output is exported. In many cases (e.g. oil drilling), some intermediates are imported so the point would be on the bottom edge but near the southeast corner. We label affiliates marked by intermediate levels of local sales and local sourcing as 'networked FDI'; these facilities are most naturally viewed as part of international supply chains.

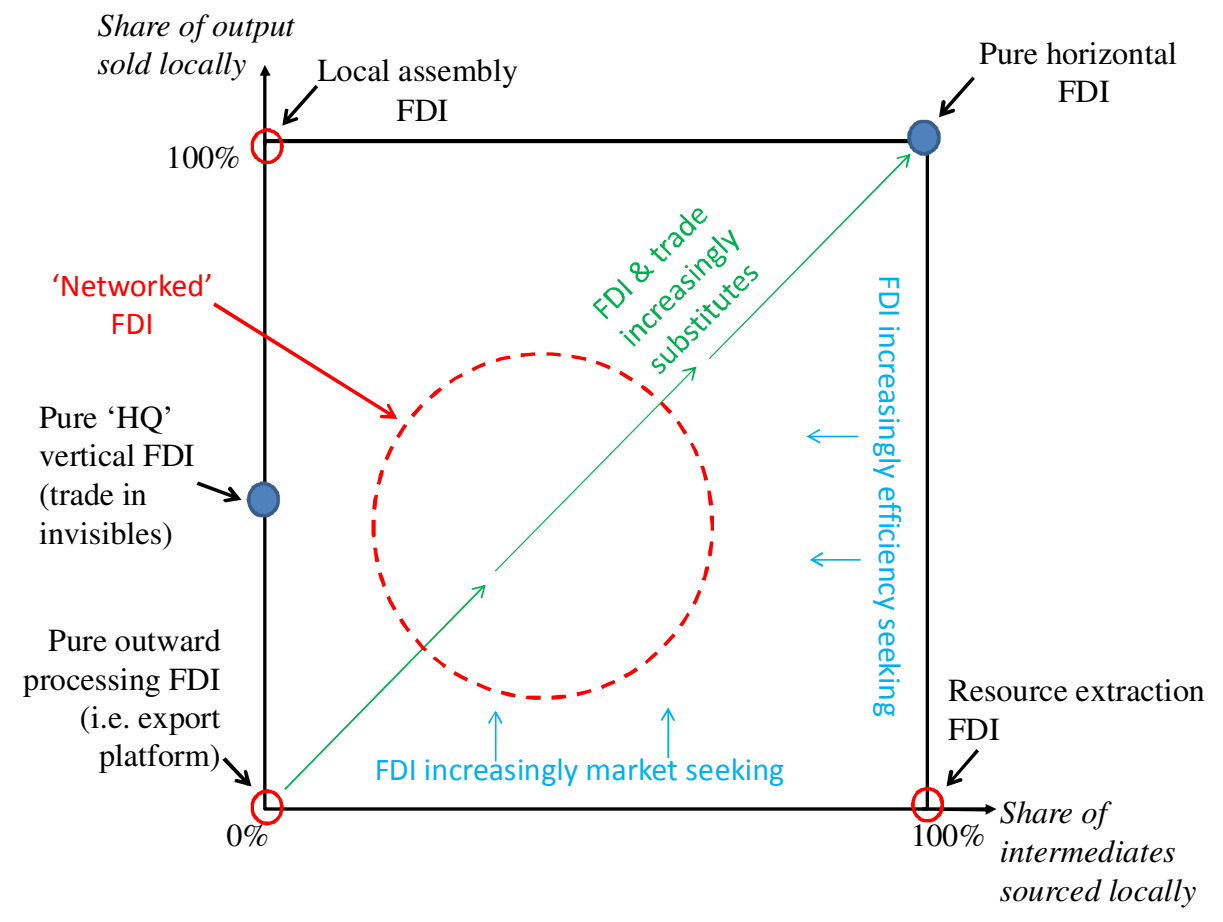

Figure 1: The sales-sourcing box diagram.

The substitutability of FDI and trade increases along the southwest to northeast diagonal. At one extreme, pure horizontal FDI extinguishes all trade, while at the other extreme, outward processing FDI maximises trade in both intermediates and final goods. The horizontal-ness of affiliates rises as we move northwards in the box and the vertical-ness rises as we move westwards.

Of course, this is a very rough classification and many nuances are hidden. One important aspect that we cannot get at with our data is the role of technology. Authors such as Fosfuri 
and Motta (1999), Siotis (1999), and Carvalho, Duysters and Costa (2010) stress that multinationals (MNCs) may place affiliates abroad to exploit existing, firm-specific technology advantages (technology exploiting; see Love 2003, Driffield and Love, 2003) but others do so to acquire technology (technology acquiring). Our approach would be much improved if we could get a handle on the role of technology in FDI motives. This is a topic for future research.

\subsection{FDI and development strategies}

The sales-sourcing box can also illustrate typical development strategies involving FDI (Figure 2). The traditional import-substitution strategy, for example, involves starting with local assembly and pushing multinationals to produce more intermediates locally. The eventual goal is to achieve export competitiveness with a high degree of local sourcing. This would show up as a move from the northwest corner towards the southeast corner.

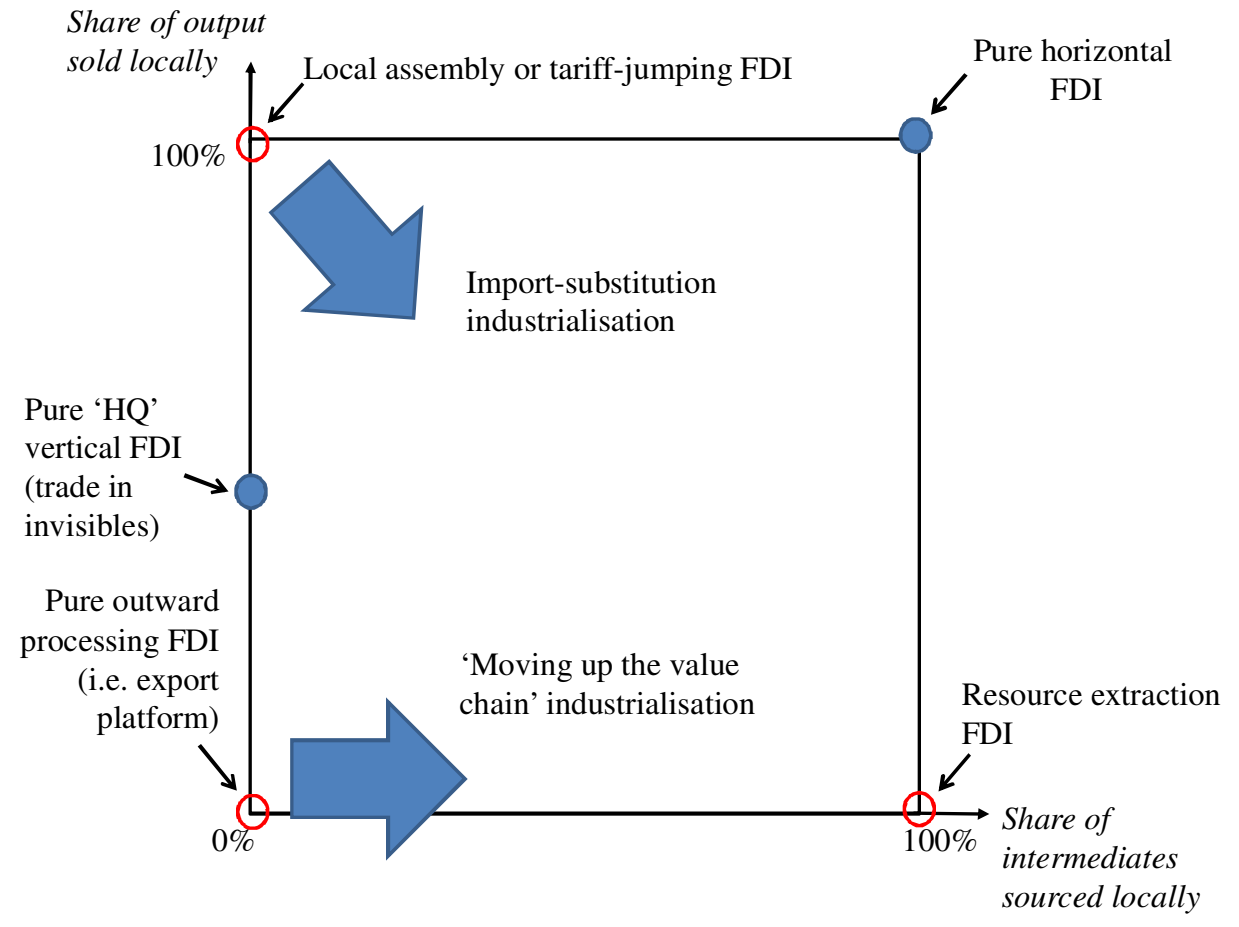

Figure 2: FDI and development strategies

The $21^{\text {st }}$ century version of this - pursued by China and other East Asian nations - starts from the southwest 'outward processing' point and seeks to induce multinationals to source more intermediates locally. This is a pure 'eastward' move from the lower left-hand corner. In some cases, there is also a desire to develop the local market for the final good. This would be a push to move affiliates' position north-eastwards.

\section{Japanese affiliates' sales and sourcing: Aggregate data}

Our data includes extensive firm-level information on Japan's foreign affiliates called "The Survey on Overseas Business Activities" prepared by the Research and Statistics Department 
of the Japanese Ministry of Economy, Trade and Industry (METI). ${ }^{14}$ The yearly survey is conducted by METI using a questionnaire based on survey forms and covers all Japanese affiliates in all sectors and in all nations. The parent firm and each foreign affiliate are surveyed separately. The reply rate of parent firms is almost universal; that of affiliates is about $70 \%$ in 2005 and 59\% in 1996 (the first year in which the data is in electronicallyaccessible form). The data, which is confidential, is prepared and managed by METI. The survey questions asked cover a very broad range of economic issues including the number of employees, assets, purchases, and some intellectual property indicators, etc. While the basic questions are constant across years, there are some annual variations in a subset of questions. The trend has been for the survey to be simplified in recent years.

The sector classifications used in the survey do not correspond to international practices (e.g. UNIDO or OECD classifications), but they are broken down into 80 sectors in 2005. In earlier years, the classification scheme involved more sectors but their decomposition was slanted toward 'old' industries.

In this paper, we focus on the sales and sourcing patterns of firms, but we start with a few summary statistics. ${ }^{15}$ Table 1 shows that the biggest sectors, by far, are services and machinery. The biggest host regions are Asia, North America and the EU; Asia's total exceeds that of the sum of all other regions.

Table 1: Number of affiliates by region by sector, 2005.

\begin{tabular}{llllllllr}
\hline \hline & & \multicolumn{1}{c}{ Middle } & North & \multicolumn{2}{c}{$\begin{array}{c}\text { South } \\
\text { America }\end{array}$} & $\begin{array}{c}\text { Sector } \\
\text { Oceania }\end{array}$ \\
\hline Services & Africa & Asia & EU & $\begin{array}{c}\text { East } \\
\text { Amica }\end{array}$ & total \\
Machinery & 82 & 3,365 & 1,570 & 56 & 1,511 & 284 & 541 & 7,409 \\
Chemical & 27 & 3,425 & 702 & 10 & 968 & 57 & 188 & 5,377 \\
Primary & 4 & 698 & 177 & 2 & 209 & 14 & 26 & 1,130 \\
Metal \& metal products & 7 & 421 & 94 & 2 & 158 & 133 & 74 & 889 \\
Light manuf. & 7 & 503 & 31 & 1 & 127 & 11 & 18 & 698 \\
Region total & 1 & 580 & 27 & & 50 & 11 & 20 & 689 \\
\hline \hline
\end{tabular}

Note: See appendix for list of sectors under each of the six broad headings.

Looking across sectors, we see a typical Pareto distribution of the importance of the sectors. Using data for 2005, we see that in terms of assets and workers employed a handful of sectors account for the lion's share of global totals. The most important in terms of assets are wholesale trade, financial and insurance, auto parts, communication equipment, motor vehicles, electronics, and chemicals. In terms of employment, the ordering is somewhat different, but electronics and financial services are significantly lower while clothing and retail trade are significantly higher. Using either metric, the biggest FDI sectors are electrical and mechanical machinery, clothing, and certain types of services that require local presence. Figures for the total number of nations with at least one affiliate present a broadly similar picture.

\footnotetext{
${ }^{14}$ It is "Kaigai Jigyou Katsudou Kihon Chousa" in Japanese.

${ }^{15}$ The questionnaire of the data asks about imports or local purchases of intermediate inputs and raw materials (i.e. sourcing) and exports or local sales of final products.
} 


\subsection{The sales-sourcing patterns: Affiliates' trade patterns}

While we have data by nation by sector for each affiliate, we work with figures aggregated across all affiliates within a country or region to bring the data's dimensionality to a manageable level. This helps us develop empirical hypotheses that can be tested econometrically on the firm-level data.

The first task is to see how Japanese affiliates are placed in the sales-sourcing box diagram. Specifically, we characterise each sector (aggregating over all affiliates in all nations) according to the share of its output sold locally as well as by the share of its intermediate purchases that are acquired locally (these purchases do not concern factors of production like labour, capital and technology). Each sector is plotted as a point in the sales-sourcing box. In keeping with the two-nation worldview, we aggregate the sales and sourcing information into local (i.e. from or to the host nation) and non-local. This gives us 68 data points (one for each two-digit sector), each with two characteristics - the share of local sales and the share of local intermediates. These are displayed in a scatter plot (Figure 3).

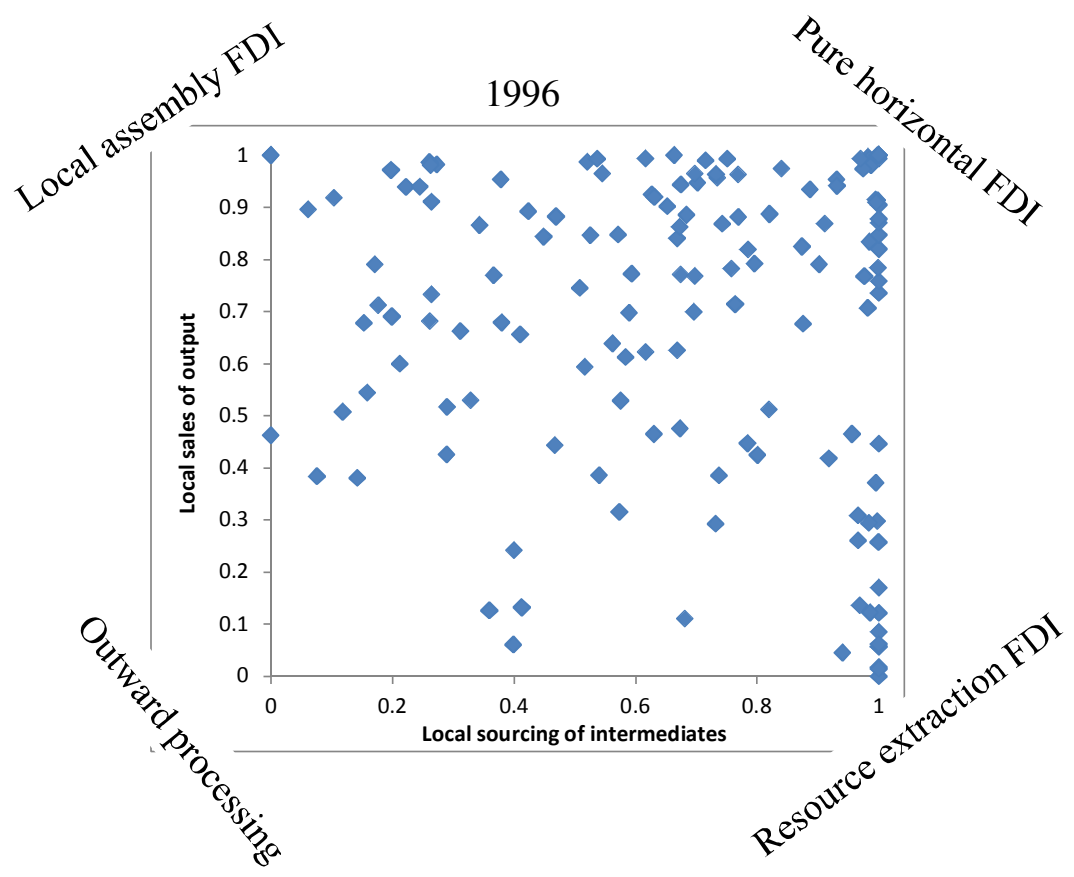

Figure 3: Sales and sourcing, Japanese affiliates, all host nations, 1996.

Figure 3, confirms that the canonical horizontal or vertical distinction is useful but inadequate. In 1996, the horizontal motive covers a large number of sectors as can be seen from the mass of data points along the north-eastern corner and eastern edge more generally. Indeed if we ignored data on affiliate's sourcing patterns, the 1996 would suggest that most affiliates were examples of horizontal FDI. This feature of the data probably explains why early empirical work, such as Brainard (1997), found that horizontal FDI was dominant. Such studies focused only on the sales patterns of affiliates. To see this, we collapse all points onto the box's eastern edge to get a histogram of horizontal-ness (Figure 4). This shows the predominance of sectors that sell $90 \%$ or more of their output locally. 
Moving away from the box's eastern edge, we see that many data points display intermediate shares of both local sales and local sourcing. In Yeaple's terms, this is 'complex' FDI. It is also interesting to note that in 1996 there were no sectors in the outward processing corner (remember we have aggregated across all affiliates in all regions so even if many affiliates in, say, IT equipment, were engaged in outward processing, the average need not show up in the southwest corner).

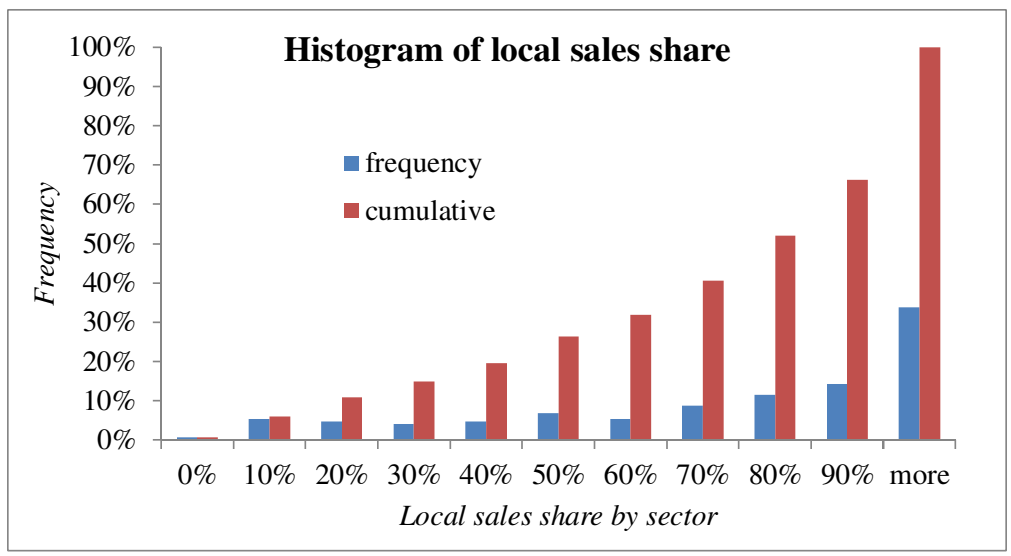

Figure 4: Dominance of local sales, 1996.

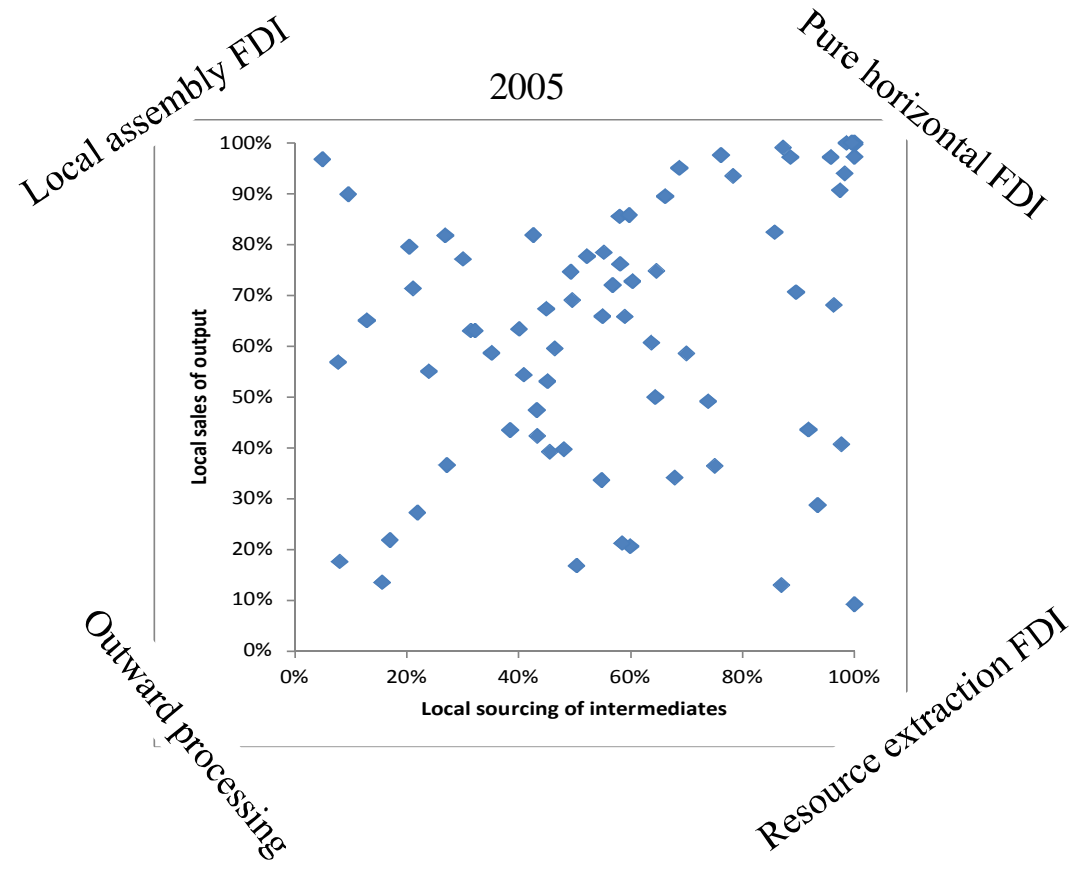

Figure 5: Sales and sourcing, Japanese affiliates, all host nations, 2005.

As production unbundling advanced, the sales-sourcing patterns of Japanese FDI changes dramatically, as the comparison between 1996 and 2005 in Figure 5 and Figure 3 shows. Although the sector classifications changed between the two years, the broad picture is clear - most sectors saw a decrease in the local sourcing of intermediates. The idea here is that progress in information and communication technology made it increasingly economic to spatially unbundle production and disperse production stages to locations with attractive 
production costs (Baldwin 2006). A few sectors remain as classic horizontal sectors but there a greater mass of sectors in the centre.

In particular, Figure 5 shows the emergence of what we called 'networked FDI' - i.e. FDI where the affiliates import substantial shares of their intermediates and export substantial shares of their output. In this sense, trade and investment became far more entwined between 1996 and 2005.

\subsection{Focus on sectors}

As might be expected, the sales-sourcing patterns vary according to the sector of the affiliate. After all, the key determinant of market-seeking versus efficiency-seeking FDI depends upon sector-varying characteristics such as scale economies, natural and manmade trade frictions, and modularity of the production process. Figure 6 divides our two digit sector points into six broad categories: light manufacturing, chemical, metal and metal products, machinery, service and primary sector. The charts contain some surprising features.

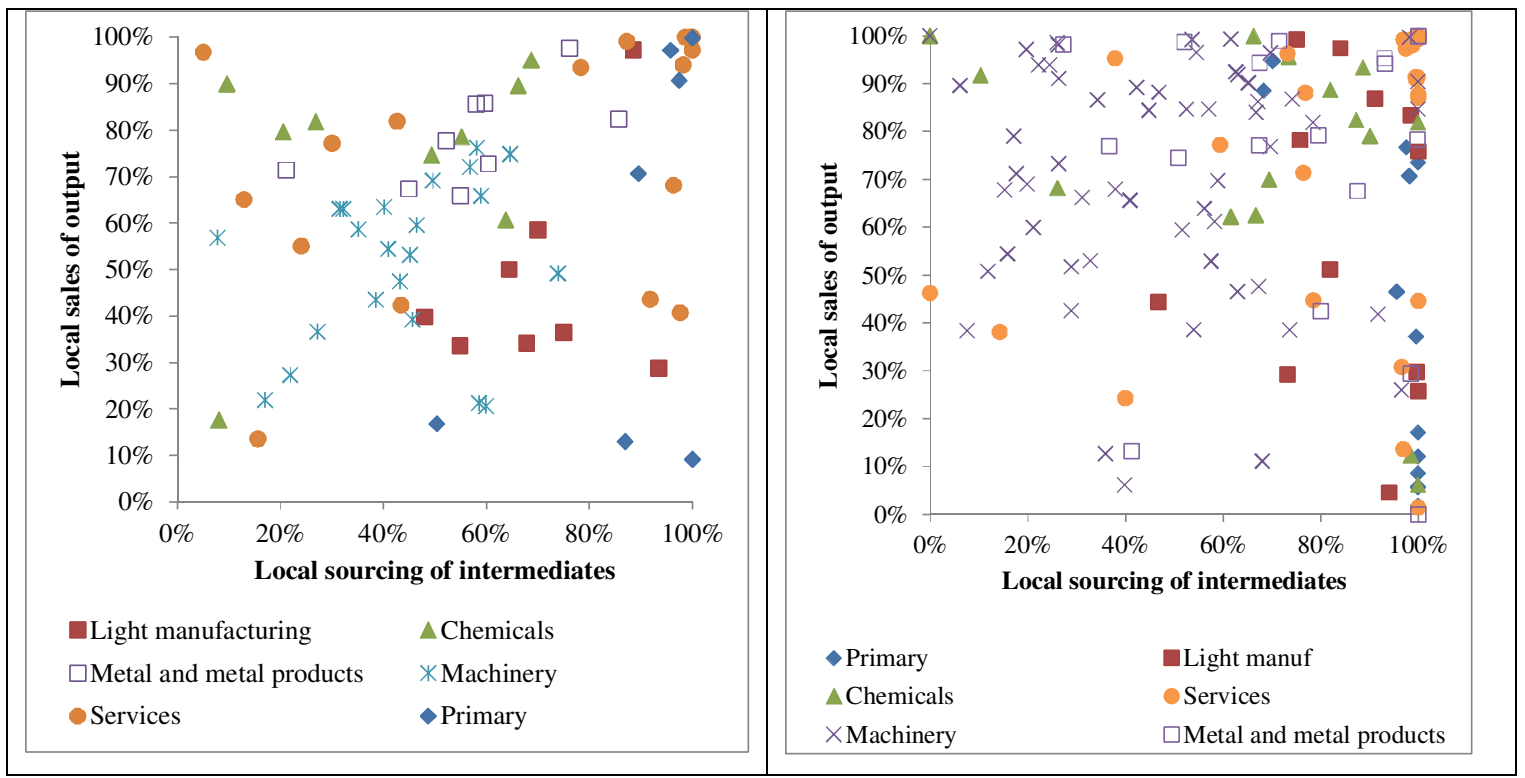

Figure 6: Sales and sourcing by sector, 2005 (left) and 1996 (right).

Note: See appendix for list of sectors under each of the six broad headings.

Focusing on 2005 data (left panel), we see that service sectors are the sectors with patterns closest to the tradition horizontal or vertical FDI. For example hotel and restaurant, real estate, and advertising rely almost entirely on local intermediates and sell virtually all output locally. More generally, service sectors tend to have extreme sales-sourcing patterns. The communications industry, for example, sources only $5 \%$ of intermediates locally but sells $95 \%$ to the local market. The transportation-service sector sources only $16 \%$ locally and sells only $14 \%$ locally.

Primary sectors also tend to be extreme in their trade patterns, generally showing up on the eastern edge of the box. Extractive sectors such as forestry and metal mining have very low local sales but very high local sourcing of intermediates. Note that we are measuring intermediates as total purchases other than those related to labour, capital and technology. 
There is also a group of primary sectors that closely fit the trade pattern of pure horizontal FDI. Beverage manufacturing, construction, and food manufacturing are examples of sectors with very high local sourcing and sales shares.

The classic FDI sectors - manufacturing of consumer and capital goods, which account for the bulk of FDI by value - tend to have more intermediate sales-sourcing configurations. Interestingly, the machinery sectors tend to be stretched out along the 45 degree line with their sales and sourcing shares tending to rise or fall together. On the high side, Motor vehicles as well as auto parts and accessory manufacturing have sales and sourcing shares around $60-70 \%$. Other transportation equipment, by contrast, has scant local sales and sourcing; the numbers are $17 \%$ and $22 \%$ respectively. Such low shares suggest that these affiliates are adding value at intermediate production stages and passing their output down the international supply chain.

Chemicals tend to display high local sales shares with variable local sourcing shares. For example, medicines, chemical fertilizers and cosmetics have local sourcing shares under $30 \%$ but local sales shares over $80 \%$. Finally, light manufacturing sectors (e.g. textiles, clothes, wood, and paper products) tend to have patterns that are shifted toward the resource extraction corner (100\% local sourcing and $0 \%$ local sales) compared to heavy-industry sectors.

The pattern for 1996 is difficult to compare exactly to 2005 's given the changes in sector definitions, but much of the sector features in 2005 are also found in the 1996 data. For example, services and primary sectors have extreme sales-sourcing patterns, and light manufacturing sectors generally have higher local sourcing shares than machinery sectors. One big change is the truncation of variation in machinery sectors. In 1996, many machinery sectors had local sales and sourcing shares over $80 \%$. By 2005, however, no machinery sectors had more than $80 \%$ sales and sourcing shares. This surely reflects the internationalisation of supply chains in the machinery sector.

\subsection{Regional variations}

The patterns depicted hereto reflect an average across all nations. As it turns out, there are important differences among the sales-sourcing configurations of Japanese affiliates in the three major host regions - Asia, North America and the EU. Figure 7 shows the 2005 figures for sectors located in EU nations (left panel) and in Asian nations (right panel). Note that here local means sales within the individual host nation, not within the region (e.g. EU or Asia). Both panels show that FDI in both regions is what might be called 'networked' FDI (excluding primary and service sectors). That is, the affiliates are very outward oriented in that they import the bulk of their intermediates and export the bulk of their output.

For the EU, very few sectors have local sales shares over $50 \%$ or local sourcing shares over $60 \%$. This is a natural consequence of Japanese firms viewing the EU as a single market; they tend to place a facility in a limited number of EU nations, exporting from these to other EU members. Likewise the local sourcing is limited given the relatively small nature of many EU nations (this limits the range of available intermediates).

The sectoral sales-sourcing patterns in Asia are fairly similar to the EU patterns. Services and primary tend to have extreme patterns. However, the Asian pattern for services seems to reflect the more fragmented nature of Asian national markets for services. That is, many of the services appear to be examples of pure horizontal FDI with mostly local sourcing and sales. In the EU, by contrast, many of the service sectors sell less than $70 \%$ locally and about half of them source less than $50 \%$ locally. When it comes to the big volume FDI sectors - 
machinery - the Asia and EU pictures are both marked by the networked features, namely intermediate shares of local intermediate purchases and intermediate shares of local sales.

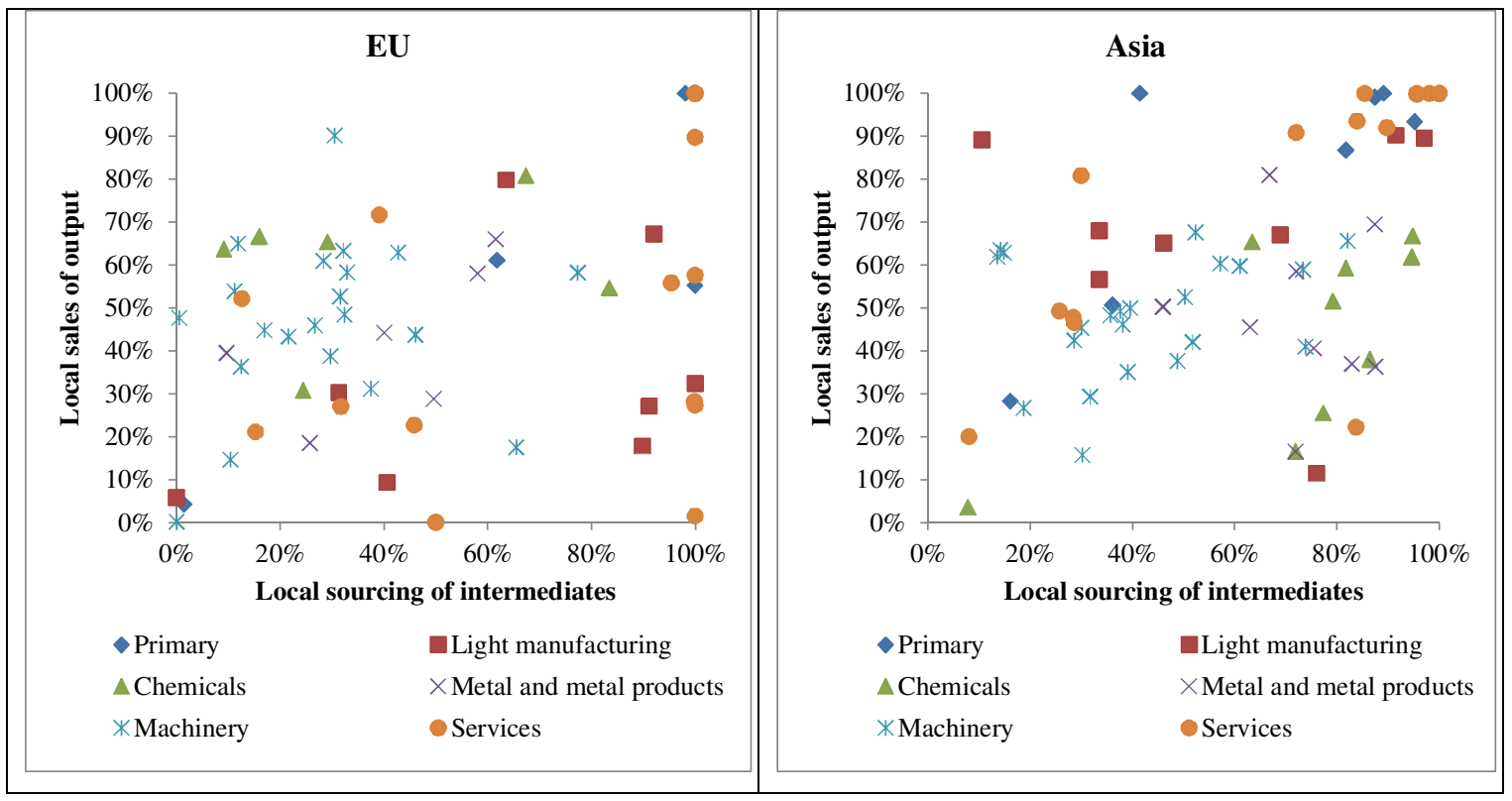

Figure 7: Sales and sourcing by sector, EU and Asia, 2005.

Note: See appendix for list of sectors under each of the six broad headings.

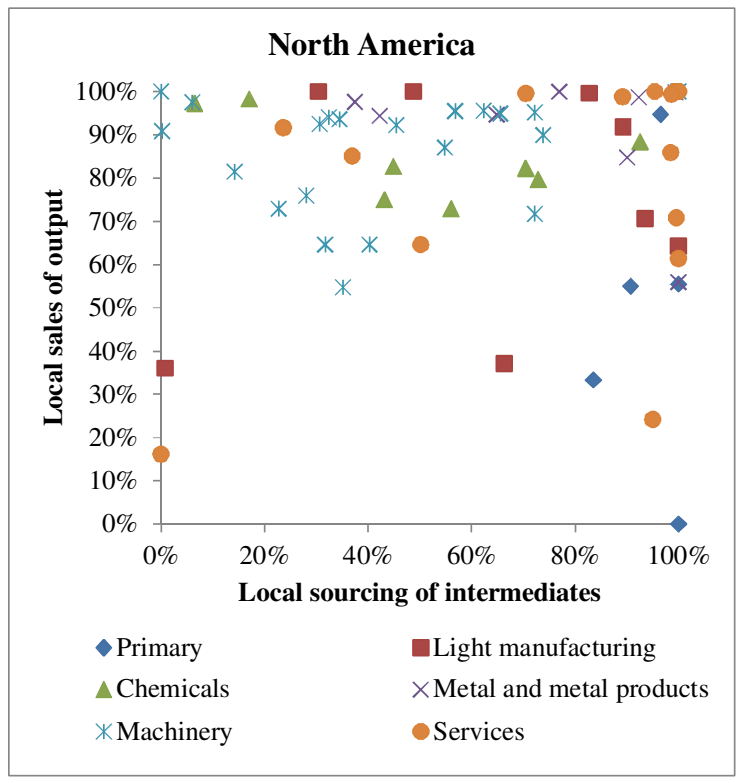

Figure 8: Sales and sourcing by sector, North America, 2005.

Note: See appendix for list of sectors under each of the six broad headings.

The North American sales-sourcing patterns are strikingly different, especially for manufacturing sectors (chemicals, light manufacturing, and machinery). The most salient feature is the dominance of local sales. Almost every sector sees more than $50 \%$ of output 
sold within the host nation (i.e. within US, Canada or Mexico). This outcome is probably due to the vast size of the US market, which is almost as large as the EU market but which consists of one nation rather than dozens.

\section{The multi-nation sales-sourcing patterns}

Hereto we have used the two-nation perspective; sales and sourcing is either home or foreign. This was a natural point of departure for our analysis since the canonical theory - which still shapes today's theory and empirical work - was cast in a two-country world. Given the extensive literature on global value chains, the next nature step is to turn to a more refined categorisation of the sales-sourcing patterns. Fortunately, our data allows us to take a step in this direction. In particular, we turn to a four-fold categorisation of the sales and sourcing patterns: to/from local, to/from Japan, to/from other nations in the region, to/from rest-ofworld.

To provide a backdrop for our investigation of sector variations, we first consider the aggregate sales-and-sourcing patterns of all Japanese affiliates in all sectors and all nations. The left bar of Figure 9 decomposes the destination of foreign affiliate sales into local sales, sales back to Japan, sales to other nations in the region, and sales to all other nations (RoW). The regions here are North America, Asia, South America, the EU, Oceania, and Africa. The right bar provides the same geographical breakdown for purchased inputs (intermediates).

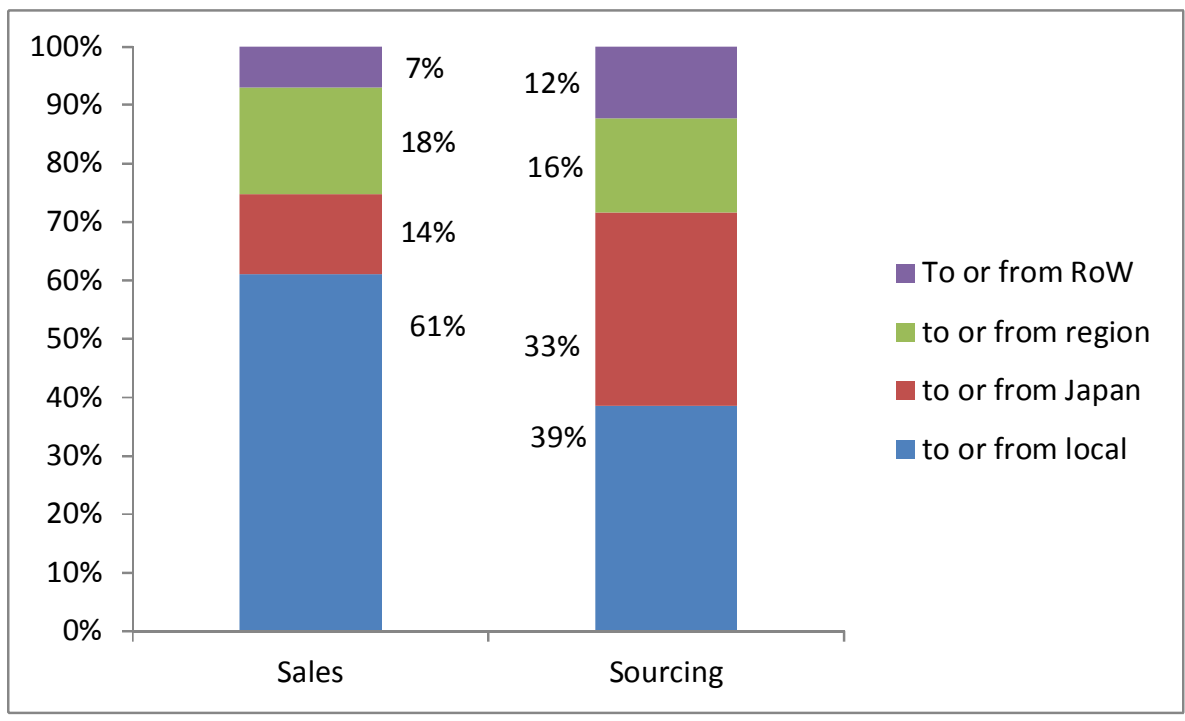

Figure 9: Sales and source by region, 2005, all sectors and nations

A key fact shown by Figure 9 is that $25 \%$ of sales are to neither the home nation (Japan) nor the host nation. Moreover, $28 \%$ of purchased inputs are not from home or host nations. Both facts sit uncomfortably with the two nation thinking and suggest that empirical tests based on this home-or-foreign aggregate will lead to misleading results. For example, looking only at sales, the horizontal FDI story would look good (60\% of sales to host market), but looking only sourcing the horizontal FDI story looks bad (only $39 \%$ of inputs purchased locally). The two-nation vertical story also struggles to account for the main facts as only $33 \%$ are sourced from the home nation. Of course squashing our data to fit the two-nation model, we would add the sourcing from Japan, the region and RoW to get a feeling for the non-local content. 
The result would be that the vertical story looks much better than the horizontal story as $60 \%$ of intermediates are non-local.

\subsection{Sectoral perspective}

The average numbers in Figure 9 hide massive cross-sector variation. The figures for all our sectors (again aggregated across all Japanese affiliates worldwide) are shown in Figure 10. The sectors have been ordered according to a crude 'networked FDI index' which reflects the average share of sales and sourcing from third nations. This is a very rough measure of the extent to which production chains are internationalised in complex ways.

Quite a few sectors at the top of the chart - i.e. sectors with large shares of non-local, nonJapanese sales and sourcing - are generally viewed as being thoroughly involved in networked production chains. These include electronic equipment, textiles, chemicals, and machinery sectors. There are also some surprises, for example, the high ranking of the finance and insurance sector. 


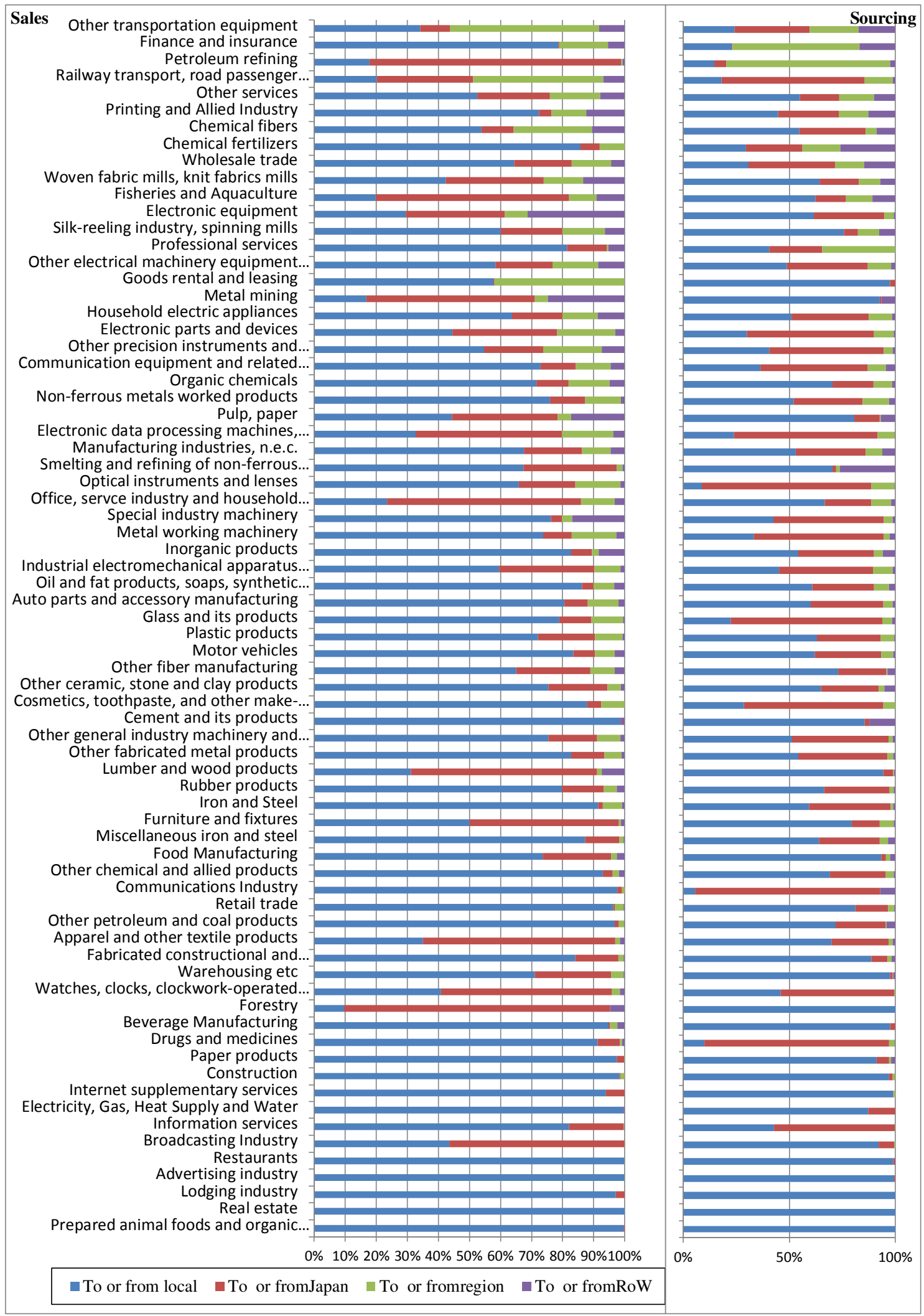

Figure 10: 4-way sales-source pattern by sector, 2005, all nations 


\subsubsection{Focus on machinery}

The production unbundling phenomenon has mostly occurred in the machinery sectors especially in the mechanical machinery and electronics sectors. Here we focus on the sales and sourcing patterns in these sectors, again aggregating across all firms in all regions. In essence, Figure 11 pulls out and magnifies several bars from Figure 10.

The chart arranges the sectors by order of importance of local sales. The motor vehicles sector is the top sector on this dimension (largely due to trade, investment and industry policies aimed at promoting local production, or at least local assembly, of autos and small trucks). Averaging across all host nations, over $80 \%$ of outputs are sold locally, but only $60 \%$ of the inputs are purchased locally. At the other end of the scale we have office and household machines where only about a fifth of output is sold locally. A very large share is sold to Japan and about $15 \%$ is sold to third markets. The networked feature of FDI in this sector can be seen by noting that about $40 \%$ of the inputs are imported. This strongly suggests that affiliates in this sector are involved in an international production network where some parts are imported from Japan or third nations in the region, while the best part of output is sent back to Japan.

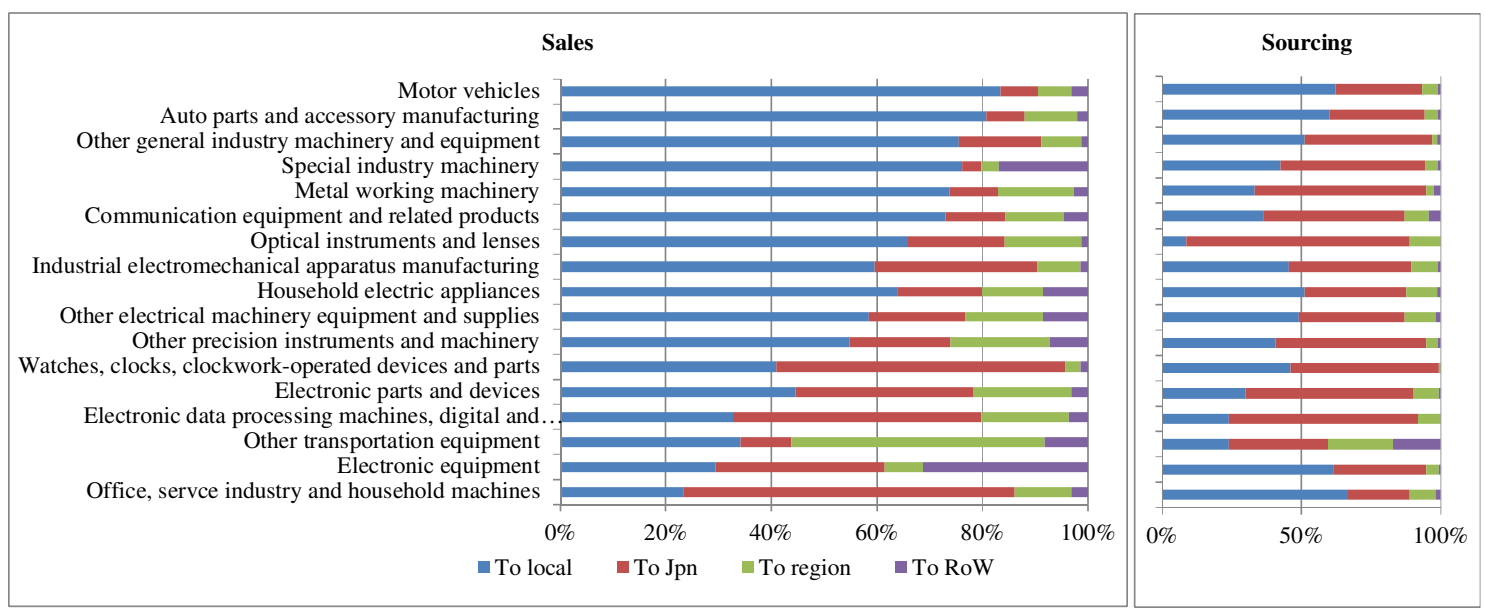

Figure 11: 4-way sales- pattern, machinery sectors, 2005, all sectors and nations.

Electronic equipment is another sector where FDI seems to be networked. Almost $75 \%$ of intermediates are imported (about half of this from Japan) and about $70 \%$ of the output is exported - mostly to other nations in the region. Similar patterns can be found in computers (electronic data process machines), electronic parts and devices, other transport equipment and precision instrument sectors (watches and other precision instruments).

\subsubsection{Focus on electronics in Asia and Europe}

To zoom in more closely on a sector where we expect network FDI to feature strongly in the data, we narrow our focus to the three electronics sectors in our data and limit the analysis to 2005. As we are only looking at three sectors, we can breakdown sales-sourcing patterns by nation (but aggregating over all affiliates in each host nation). We start with the most networked region, namely Asia.

Starting with the sales pattern for phones and related products (top left panel marked 1501), we see that except for China, most of Japanese affiliates' sales are not local. Much is 
exported back to Japan, to other Asian nations, or to the EU or the US. The export to nonAsian markets however is quite marginal; the vast majority of sales are regional. An even more extreme regionalization of the supply chain shows up on the sourcing side (top right panel). Virtually all the inputs purchased by affiliates located in an Asian nation are from Asia itself. Local purchases are small (except in Hong Kong).

This is clear evidence that 'global value chains' is a misnomer; value chains in Asia are regional, not global. The regionalization of sales-and-sourcing in computers (two charts in the middle panel) is even more marked. With the exception of Singapore, very little of the computer production is sold locally - almost all of it is exported to other Asian nations with Japan being a very large importer. When we compare the sales pattern with the sourcing pattern, we see that Japan is also a very large supplier of intermediate inputs for computers. Taken together, this suggests that computers are a classic case where Japanese computer makers offshored some aspects of their production line to nearby, low-cost Asia locations but maintain substantial production of intermediates at home.
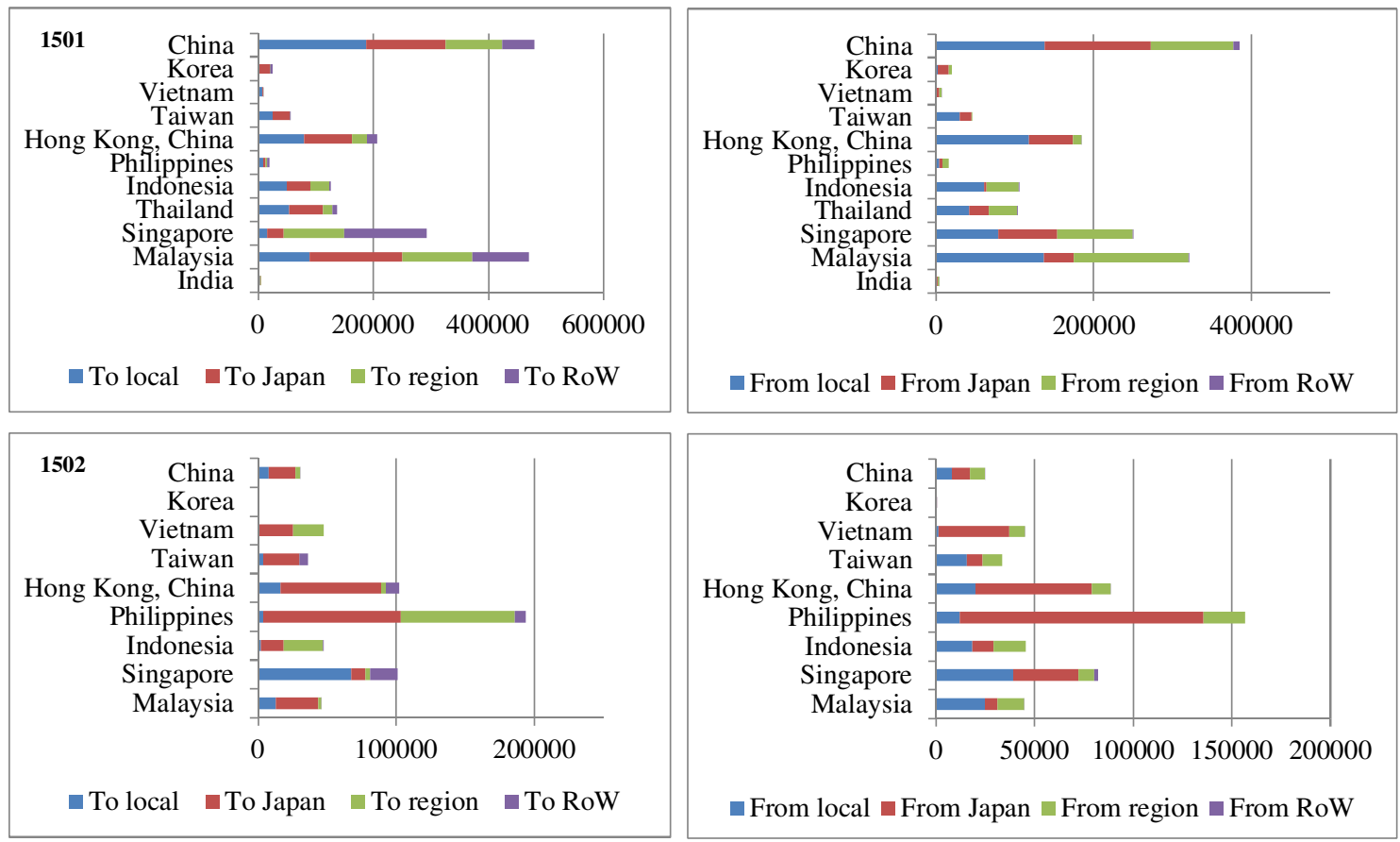

$\square$ From local $\square$ From Japan $₫$ From region $\square$ From RoW
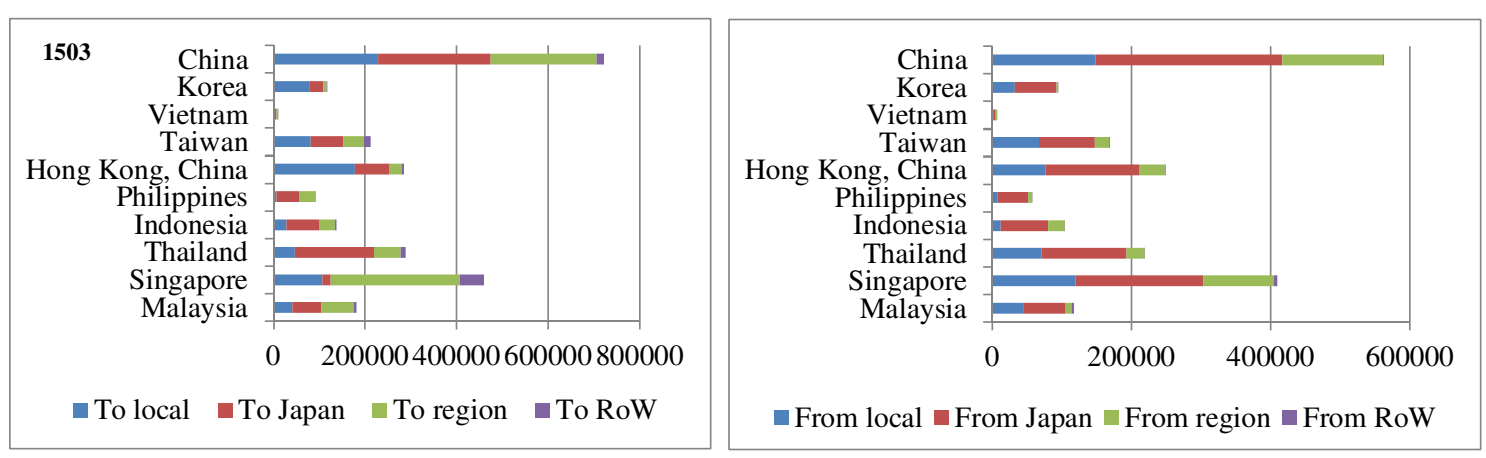

Figure 12: Networked FDI in Asia, electronics sectors, 2005.

Note: The left panels show sales; right panels show sourcing; 1501 is 'Communication equipment and related products' (final goods including phones, fax, radio, TV, stereo, tape recorders, Karaoke machines, etc.); 1502 'Electronic data processing machines, digital and analogue computer, equipment and accessories' (final 
goods), and 1503 is 'Electronic parts and devices' (parts and components such as semiconductors, tuners, transistors, condensers, etc.).

As showed in the bottom panels, the sector marked 1503 (electronic parts and devices sector), displays a high local sales share but also very high import shares of inputs from other Asian nations, especially Japan. As these are parts, the local sales must be feeding into a supply chain.
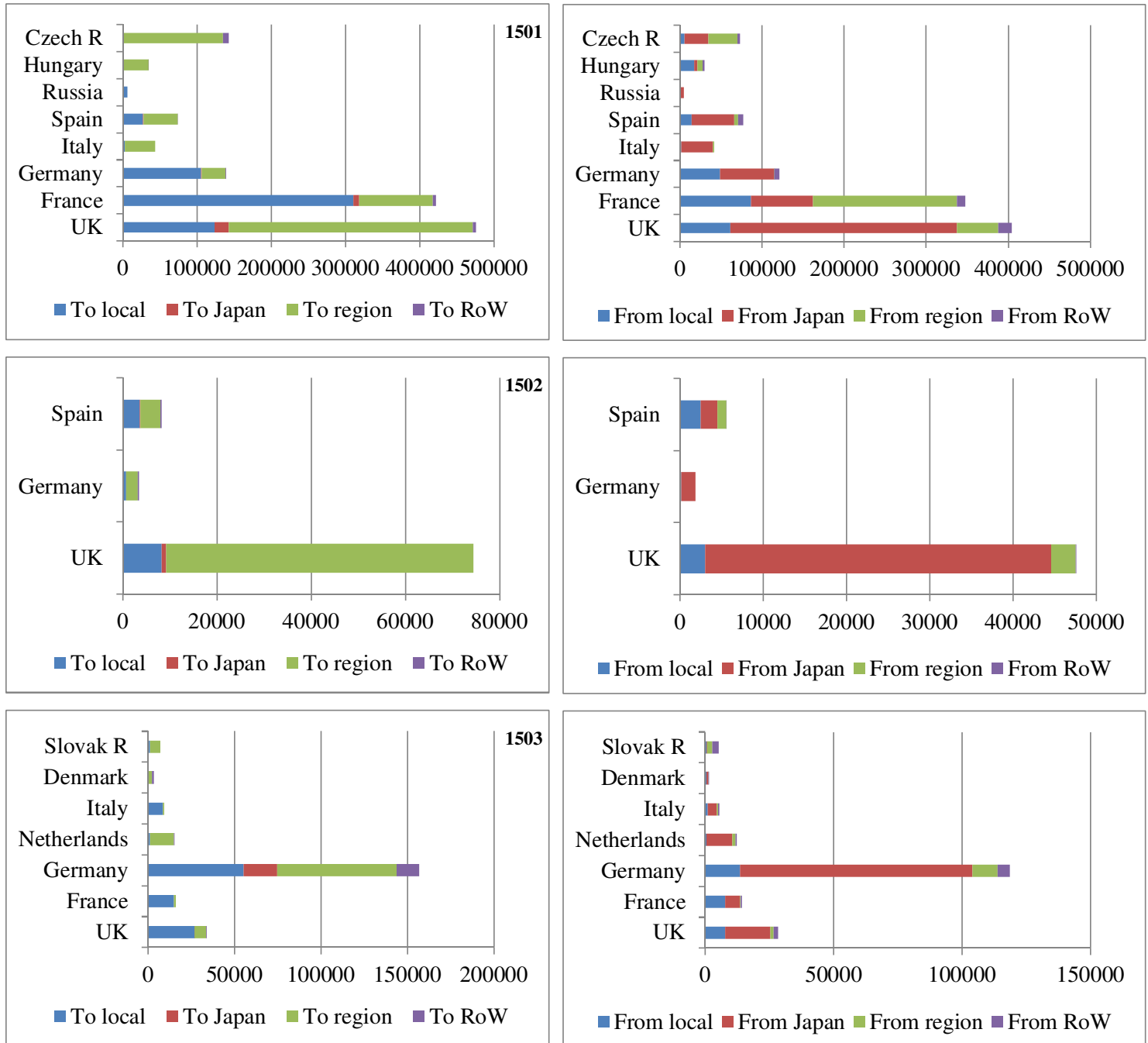

Figure 13: Networked FDI in the EU, electronics sectors, 2005.

Note: see note to Figure 12 for category definitions.

The networked FDI features we saw in Asia are partly present in the EU, as Figure 13 shows. When it comes to parts (bottom panel marked 1503), most of the output is exported, with most of it going to other EU nations. The UK is an exception with local parts sales dominating. The sales of phones (top panel marked 1501) and computers (middle panel marked 1502) shows a remarkable emphasis on local and regional sales. Apart from small slivers of sales back to Japan, virtually all of the output of these sectors is sold in the EU. Among the EU nations, however, there are important differences. Some nations, like the 
Italy, Czech Republic and Hungary, are classic export platforms with basically all their output exported to other EU nations. Others, however, such as Germany, France and the UK, show a mix of local and export sales.

The pattern for computers (middle panel) is quite stark. The UK is the dominant host nation and it imports almost all of its intermediates from Japan while exporting almost all of its output to other EU nations. This suggests that the manufacturing of Japanese computers in the UK is basically an assembly operation.

\subsubsection{Focus on electronics in the US: The odd man out}

The broad similarity of sales-sourcing patterns in Asia and the EU stands in stark contrast to the US pattern. ${ }^{16}$ In short, Japanese affiliates in the US do not seem to be engaged in international production chains. The pattern is much more reminiscent of import-substitution assembly. Figure 14 shows the facts.

Since the FDI pattern in North America is so simple (it is mostly in the US), we can show all three electronics sectors in one figure. In the parts sector (1503) and computers (1502), the US-based affiliates buy almost $100 \%$ of their intermediates from Japan and they sell almost $100 \%$ of the output in the US. In essence, the US-based FDI is basically assembling parts from Japan into final goods - presumably to avoid importing the final goods directly. This is not pure horizontal FDI, since there is almost no local purchasing of intermediates. In the phone sector (1501), however, the US-based Japanese affiliates buy about a third of inputs locally with the rest imported from Asia, with Japan playing the dominate role. On the sales side, the pattern is almost $100 \%$ local sales.

The only hint of networked FDI in North America is found in Mexico, where the affiliates import $100 \%$ of their inputs from the region (which must mean from the US given the lack of Canadian production).
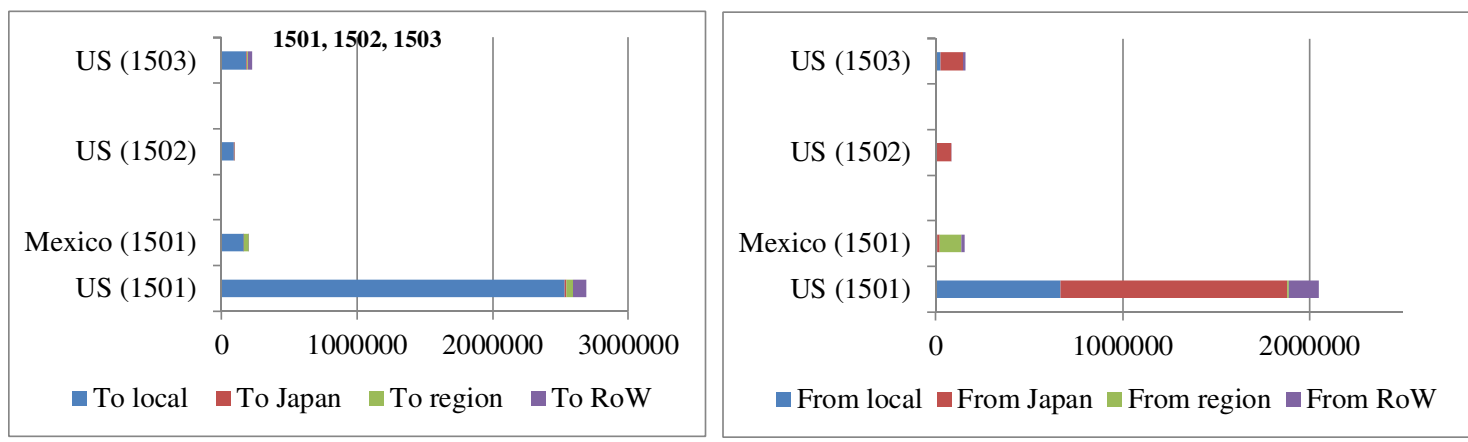

Figure 14: Electronics FDI in the US, electronics sectors, 2005.

Note: see note to Figure 12 for category definitions.

\subsubsection{Focus on auto sectors}

To give a flavour of the vast range of multinational activities - and thus strengthen our warning against the broad generalizations that often emerge in the empirical literature - we

\footnotetext{
${ }^{16}$ We note that this discussion hinges on the boundary of nations and regions. The US is a large economy and composed of 50 states. If the data is disaggregated at the state level, results might change and be closer to EU case. Likewise, if EU (or Euro) member countries are aggregated as one country, our results in the European case might change.
} 
look more closely at the auto sector nation by nation (grouped by the three main FDI hosting regions, Asia, the EU and the US).

Figure 15 shows the facts for motor vehicles and auto parts for the eight Asia nations with significant FDI production by Japanese affiliates. Looking at the left panels we see that sales in the auto sectors are dominated by the local market. This is the polar opposite of the electronics industry where exports are the main business of the affiliates. The local market emphasis is stronger in final vehicles than it is in parts, but in both sectors the lion's share of sales is made inside the host nation. Thailand is an exception with about a third of its sales exported, much of it to the US and the EU. The sales pattern in autos is more international on the whole and some Asian nations, such as Vietnam and the Philippines, export their entire output. Another key difference is the importance of the Japanese market as a destination for auto parts. While this is always a moderate share (except for Vietnam), it is significant in most host nations. Vietnam is perhaps the classic example of what seems to be the offshoring of one segment of a Japanese auto production line. Japanese affiliates in the country import basically $100 \%$ of intermediates from Japan and sell basically $100 \%$ of their output back to Japan.

The sourcing side (right panels) shows more elements of production networks, with Japan playing the largest role. However, with some exceptions (Philippines, Pakistan), a very large share of intermediates are sourced locally; the share is usually over $50 \%$.

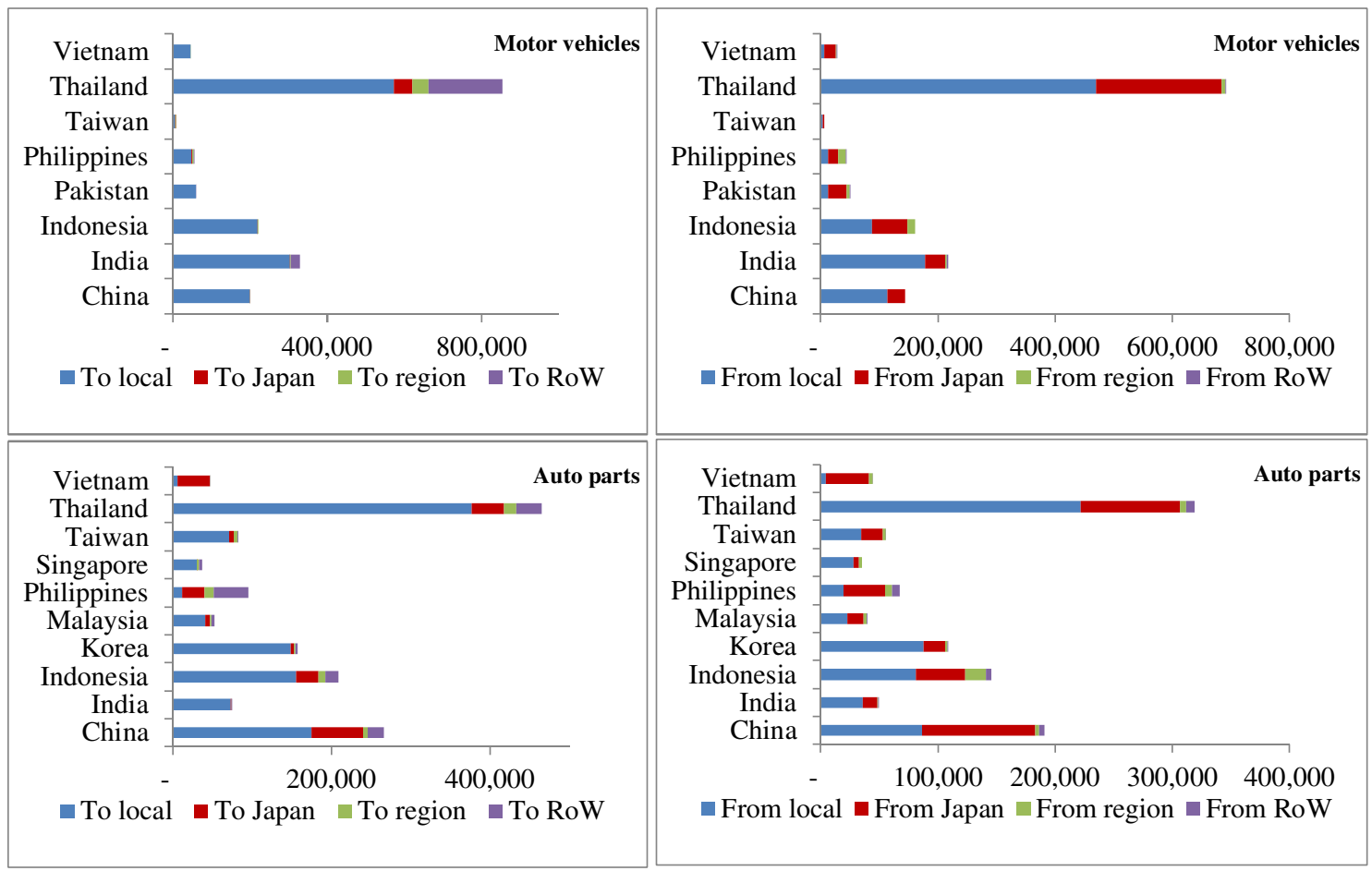

Figure 15: Sales \& sourcing, auto sectors, Asia, 2005.

Corresponding numbers for the EU are shown in Figure 16. On the sales side (the left panels), we see a dominance of local and regional markets as in Asia, but in Europe it is even stronger. There are only negligible sales of autos or auto parts beyond the region. On the sourcing side, the pattern differs sharply between final goods and parts. In several of the nations, especially the Netherlands, Hungary and Turkey, an important fraction of 
intermediates comes from local or regional sources. This suggests that there is something of a regional production network going in the EU when it comes to final autos. Auto parts, however, is marked by more of a local assembly pattern. With the exception of affiliates located in France, all of the host nations import the bulk of their intermediates from Japan or from the rest of the world (mostly Asia).

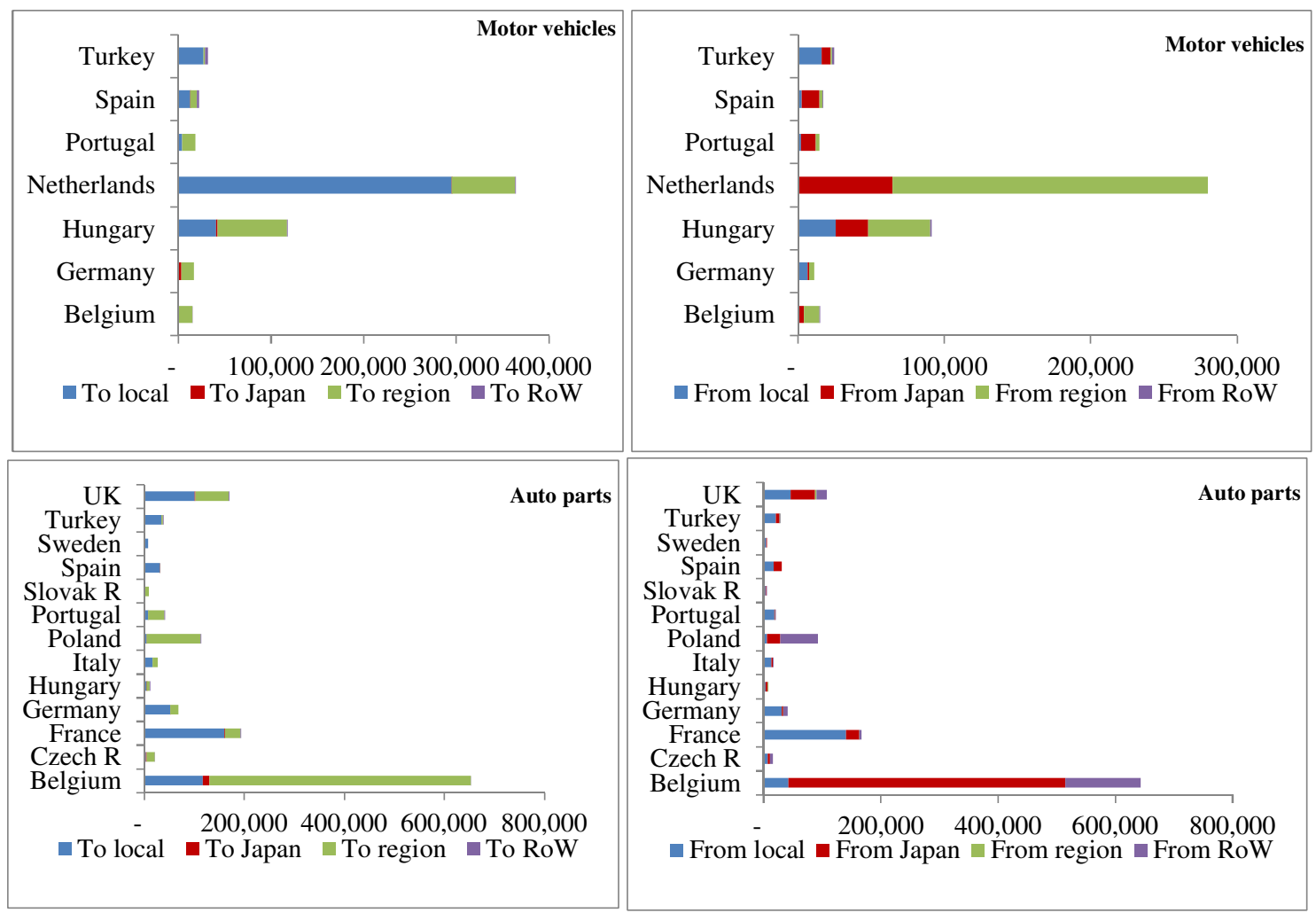

Figure 16: Sales \& sourcing, auto sectors, EU, 2005.

Finally we turn to North America in Figure 17. Here auto FDI looks very much like pure form of horizontal FDI, at least from the regional perspective. As the left panels reveal, the vast majority of auto sector outputs, both parts and final vehicles, are sold inside North America. Japanese affiliates in final autos are clearly acting as export platform for the US market. On the input side, local purchases dominate parts and final goods production in Canada, Mexico and the US, although a fifth of the intermediates are from Japan.

Overall, we see that auto sector FDI sales are highly regionalised on the sales side. Most of the vehicles and parts made in a region are purchased in the same region. On the sourcing side, Asia and North America are quite regionalised, i.e. most of the purchased inputs are from the region itself. In autos, Europe is the outlier on the sourcing side; most of its purchased inputs come from outside the region. 

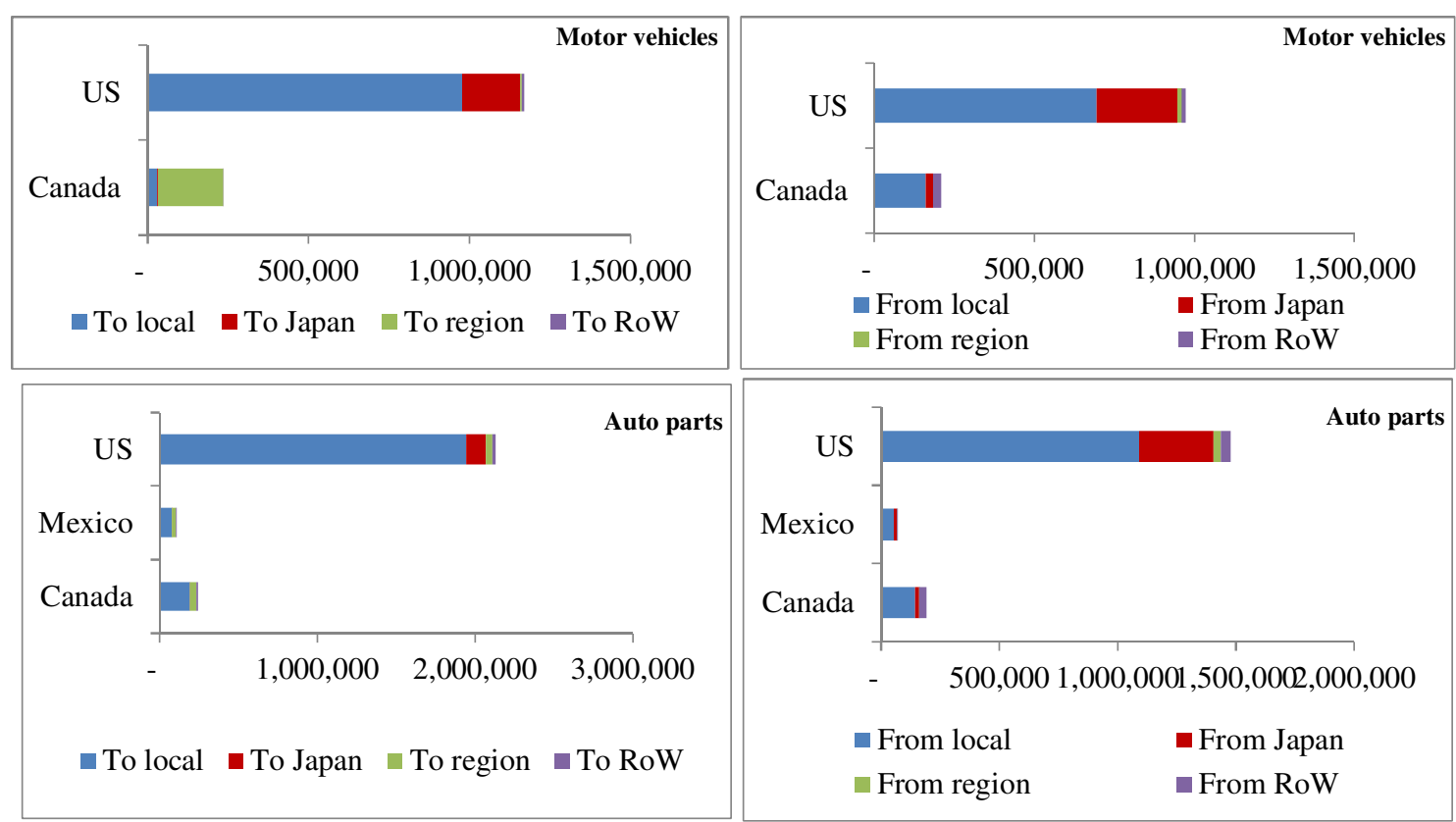

Figure 17: Sales \& sourcing, auto sectors, US, 2005.

\section{Testable hypotheses}

Our ascribing a measure of horizontal-ness and vertical-ness to each affiliate suggests a direct way of testing FDI theories. To give a couple of extreme examples, consider the case of Vietnam in the auto parts sectors. Japanese affiliates in that nation import $100 \%$ of their intermediates and re-export $100 \%$ of their output back to Japan. Given this pattern, and the nature of the sector (intermediate goods), it is absolute obvious that this FDI is efficiencyseeking rather than market-seeking. The key clue, however, is not in Vietnam's factor endowment - it is in the sales-sourcing pattern of the affiliates. At the other extreme, Japanese affiliates in the auto parts sector buy only $24 \%$ of intermediates from outside NAFTA and sell $93 \%$ of their output inside NAFTA. Again this is plainly a case of marketseeking FDI, but the tell-tale lies not in macro indicators - it lies in the trade behaviour of affiliates.

More generally, under pure horizontal FDI, production is placed abroad to economize on trade costs - not to take advantage of the host-nation's comparative advantage. Under pure vertical FDI, production is placed abroad only to lower production costs. The most obvious empirical lever to separate the two motives is the existence of trade in intermediates between the home and the host nation. In the knowledge capital model, it would be simple to prove a theorem that states that even minor trade costs mean that no intra-firm trade arises unless the FDI is motivated in part by efficiency-seeking. If the foreign affiliate buys any intermediates at all from the home nation, we know that the multinational has found it advantageous to divide the production process between the home and host nation. Straightforward revealedpreference arguments would then tell us that the cost of dividing production must be below that of producing the product all in the home, or all in the host nation. Since this exploitation of multi-nation comparative advantages is the hallmark of vertical FDI, we know that the presence of any sourcing of intermediates from the home nation indicates that the FDI is at least in part vertical FDI. This line of reasoning needs to be developed more fully, but it 
seems that using affiliates' sourcing and sales behaviour will provide a more refined test of FDI theories.

The most obvious hypotheses to test are linked to the classic hypotheses that market size and trade frictions foster horizontal-ness while comparative advantage differences foster verticalness. Our measures provide new left-hand-side variables for the classical regressions suggested by Carr et al. (2001). The two characteristics are determined simultaneously, so a system estimation strategy is called for. A further robustness check would involve estimating the system separately for sectors that clearly produce intermediate goods and those that clearly produce final goods; vertical motive should be stronger in the former than the latter.

Another set of hypotheses are related to third-nation effects, or backward and forward linkages. The pattern of sourcing should be affected by regional sales of other Japanese affiliates in the region, while the pattern of sales should be affected by regional sourcing of other Japanese affiliates in the region. This could be one way to separate demand-linked and supply-linked third-nation effects on affiliate local.

One critical question in the literature is the impact of FDI on local variables such as wages, productivity, etc. Reflections upon the possible channels for these effects suggest that the nature of the local FDI might affect the impact. For example, affiliates with high degrees of vertical-ness might be thought of as have a larger impact on local productivity, than affiliates with a high degree of horizontal-ness.

A decade of empirical studies focusing on firm size suggests another set of hypotheses. Our data would allow a search for systematic size differences in the degree of horizontal-ness and vertical-ness. We conjecture that large firms would be more likely to engage in networked FDI as they can amortise the fixed cost of organisation over more units sold. In other words, we conjecture that larger Japanese multinationals should have more intermediate values of our horizontal-ness and vertical-ness indices Smaller firms should have simpler FDI patterns fitting more neatly into the two-fold classification.

Another fruitful line of investigation would be to use the affiliate data by nation and across sectors to study how and whether multinational production in developing nations has 'moved up the value chain' - at least as far as Japanese affiliate source practices are concerned. Of particular interest would be changes in the share of intermediates sourced locally, the share sourced from Japan and the share sourced regionally. Indeed, it would seem possible to build a map of the development of the Asian production network using the increase in the number, size and sales and sourcing patterns of Japanese affiliates. This would be a partial picture as it would be limited to Japanese MNCs, however, the unique combination of FDI and trade information at the affiliate level should provide a very valuable window on to the development of regional value chains.

\section{Concluding remarks}

Early modelling of FDI focused on two motives for placing plants abroad: market-seeking and efficiency-seeking. Numerous empirical strategies have been developed to identify the importance of the two. The earliest studies found evidence for a preponderance of vertical motives (Lipsey and Weiss 1981) - a conclusion that was reversed in the 2000s (Carr et al. 2001). More recent work finds that most FDI involves a blend of horizontal and vertical motive (Alfaro and Charlton 2009, and Feinberg and Keane 2006).

Our paper offers three main contributions. First, we use Japanese-affiliate data to confirm the preponderance of mixed motives in FDI. Second, we introduce a novel way of measuring motives by assigning a degree of vertical-ness and a degree of horizontal-ness to each 
affiliate. Using this method, we find a vast heterogeneity in the internationalisation strategies of Japanese multinationals. These strategies vary across regions and across sectors (and by region-sector pairs) in intuitive ways. For example, the auto industry in Asia and Europe seem to involve much more internationally networked production structures than it does in the US.

The paper documents a large number of stylised facts, but three stand out. First, FDI in almost all sectors and almost all nations involves some 'vertical-ness', and some 'horizontalness'. The variance is so great that we suspect econometric studies aimed at establishing the predominance of one motive are not constructive. Second North American affiliates are far more 'horizontal' than those in Asia and Europe. Third, affiliates in most sectors and most nations became more vertical between 1996 and 2005.

The paper also explores the presence of regional production networks and sounds of note of caution in relying on parent-affiliate-pair characteristics to describe multinational activity. We show that $25 \%$ of Japanese affiliate sales are to neither the home nation nor the host nation and $28 \%$ of purchased inputs are not from home or host nations. In many of the classic outsourcing sectors, the shares of intermediate purchases from third-nations in the region are often in the double-digit range. The share of sales to third-nations in the regional is often even greater. These facts suggest that third-nation effects could be important in determining the location of affiliates. In short, it seems like backward- and forward- linkage forces are important in FDI. The point has been documented for backward linkages (sales) but not forward linkages (sourcing). This in turn should help inform developing nation policies with respect to sectoral FDI policies. It should be easier to get FDI in sectors where related affiliates already existing in nearby nations.

In closing, we hope that the focus on the sales and sourcing patterns of affiliates opens the door to future empirical research on the complex and fast-paced evolution of trade and investment.

\section{References}

Alfaro, Laura and Andrew Charlton, (2009). "Intra-industry Foreign Direct Investment," American Economic Review, American Economic Association, vol. 99(5), pages 2096-2119.

Antràs Pol and C. Fritz Foley, (2009). "Regional Trade Integration and Multinational Firm Strategies," NBER Working Papers 14891, National Bureau of Economic Research.

Antràs, Pol, and Stephen R Yeaple. (2013). Multinational Firms and the Structure of International Trade. In Handbook of International Economics. Vol. 4.

Arnold, Jen and Beata Jovorcik (2009). "Gifted Kids or Pushy Parents? Foreign Direct Investment and Plant Productivity in Indonesia", Journal of International Economics, 79(1).

Athukorala, Prema-chandra and Yamashita, Nobuaki, (2006). "Production fragmentation and trade integration: East Asia in a global context," The North American Journal of Economics and Finance, Elsevier, vol. 17(3), pages 233-256.

Athukorala, Prema-chandra, (2012). "Asian trade flows: Trends, patterns and prospects," Japan and the World Economy, vol. 24(2), pages 150-162.

Baldwin, Richard (2006). "Globalisation: the great unbundling(s)", Chapter 1, in Globalisation challenges for Europe, Secretariat of the Economic Council, Finnish Prime Minister's Office, Helsinki, 2006, pp 5-47. 
Baldwin, Richard and Gianmarco Ottaviano (2001). "Multiproduct Multinationals and Reciprocal FDI Dumping”, Journal of International Economics, vol. 54, issue 2, pp. 429-448.

Baltagi, Badi, Peter Egger, and Michael Pfaffermayr (2005). "Estimating models of complex FDI: Are there third-country effects?", Center for Policy Research working paper 1525-3066, Syracuse University.

Barrios, Salvador, Holger Gorg and Eric Strobl (2005). "Foreign direct investment, competition and industrial development in the host country," European Economic Review, vol. 49(7), pp 1761-1784.

Bernard, Andrew, J. Bradford Jensen, and Peter K. Schott (2005). "Importers, Exporters, and Multinationals: A Portrait of Firms in the U.S. that Trade Goods." Working Paper 11404, NBER, Cambridge, MA.

Blonigen, Bruce (2001). "In search of substitution between foreign production and exports", Journal of International Economics 53, pp 81-104.

Blonigen, Bruce A (2005). "A Review of the Empirical Literature on FDI Determinants," NBER WP No. 11299.

Blonigen, Bruce A., Ronald B. Davies, and Keith Head (2003). "Estimating the Knowledgecapital Model of the Multinational Enterprise: Comment," American Economic Review 93, 980-94.

Blonigen, Bruce, Ronald Davies, Glen Waddell and Helen Naughton (2007). "FDI in space: Spatial autoregressive relationships in foreign direct investment", European Economic Review, 51 (5), 1303-25.

Borga, Maria and William Zeile (2004), "International Fragmentation of Production and The Intrafirm Trade of U.S. Multinational Companies”, Washington, D.C.: U.S. Department of Commerce, Bureau of Economic Analysis, WP 2004-02.

Braconier, Henrik, Pehr-Johan Norbäck, and Dieter Urban (2005). "Vertical FDI Revisited," Review of International Economics 13:770-86

Brainard, Lael (1997), "An Empirical Assessment of the Proximity-Concentration Trade-od Between Multinational Sales and Trade, "American Economic Review, 87:4, pp 520-544.

Carr, David L., James R. Markusen, and Keith E. Maskus (2001). "Estimating the Knowledge-capital Model of the Multinational Enterprise," American Economic Review 91, pp 693-708.

Carvalho, Flavia, Geert Duysters, Ionara Costa (2010). "“Drivers of Brazilian foreign investments - technology seeking and technology exploiting as determinants of emerging FDI," UNU-MERIT Working Paper Series 017, United Nations University.

Clausing Kimberley (2000). "Does Multinational Activity Displaces Trade?" Economic Inquiry, 38, pp. 190-205.

Coughlin, C. and E. Segev (2000). "Foreign direct investment in China: a spatial econometric study", The World Economy 23 (1), 1-23.

Davies, Ronald (2008). Hunting High and Low for Vertical FDI, Review of International Economics, Volume 16, Issue 2, pages 250-267, May 2008

Driffield, Nigel and James H. Love, (2003). "Foreign Direct Investment, Technology Sourcing and Reverse Spillovers," Manchester School, vol. 71(6), pages 659-672 
Egger, Peter, Larch, Mario and Pfaffermayr, Michael, (2004). "Multilateral trade and investment liberalization: effects on welfare and GDP per capita convergence," Economics Letters, vol. 84(1), pages 133-140.

Ekholm, Karolina, Rikard Forslid and James Markusen (2007). "Export-platform foreign direct investment", Journal of the European Economic Association, 5(4):776-795.

Feenstra, Robert (2004). Advance international trade: theory and evidence, Princeton University Press, Princeton USA.

Feinberg, Susan and Michael Keane (2006). "Accounting for the Growth of MNC-Based Trade Using a Structural Model of U.S. MNCs." American Economic Review, 96(5): 15151558.

Fosfuri, Andrea. and Massimo Motta. (1999). 'Multinationals Without Advantages', Scandinavian Journal of Economics, Vol. 101, pp. 617-630.

Garretsen, Harry and Jolanda Peeters (2009). "FDI and the relevance of spatial linkages: do third-country effects matter for Dutch FDI?" Review of World Economics, 145 (2), 319-38.

Girma Sourafel, David Greenaway and Katherine Wakelin, (2002). "Does antidumping stimulate FDI? Evidence from Japanese firms in the UK," Review of World Economics (Weltwirtschaftliches Archiv), vol. 138(3), pages 414-436.

Girma, Sourafel and Wakelin, Katharine, (2001). "Regional Underdevelopment: Is FDI the Solution? A Semiparametric Analysis," CEPR Discussion Papers 2995.

Girma, Sourafel, Greenaway, David and Wakelin, Katharine, (2001). "Who Benefits from Foreign Direct Investment in the UK?," Scottish Journal of Political Economy, vol. 48(2), pages 119-33.

Gorg, Holger \& Strobl, Eric, (2002). "Multinational companies and indigenous development: An empirical analysis," European Economic Review, vol. 46(7), pages 1305-1322.

Gorg, Holger and Strobl, Eric, (2001). "Multinational Companies and Productivity Spillovers: A Meta-analysis," Economic Journal, Royal Economic Society, vol. 111(475), pages F723-39.

Greenaway, David and Richard Kneller, (2007). "Firm heterogeneity, exporting and foreign direct investment," Economic Journal, vol. 117(517), pages F134-F161, 02.

Grossman, Gene, Elhanan Helpman and Adam Szeidle (2006). "Optimal Integration Strategies for the Multinational Firm”, Journal of International Economics 70: 216-238, 2006.

Hanson, Gordon, Raymond Mataloni and Matthew Slaughter (2001). "Expansion Strategies of U.S. Multinational Firms," in Dani Rodrik and Susan Collins (eds.) Brookings Trade Forum 2001, Brookings Institution Press.

Hanson, Gordon, Raymond Mataloni, and Matthew Slaughter (2005). "Vertical Production Networks in Multinational Firms." Review of Economics and Statistics, 87, 664-678.

Head, Keith and Ries, John, 2003. "Heterogeneity and the FDI versus export decision of Japanese manufacturers," Journal of the Japanese and International Economies, vol. 17(4), pages 448-467.

Head, Keith and Ries, John, 2005. "Judging Japan's FDI: The verdict from a dartboard model," Journal of the Japanese and International Economies, vol. 19(2), pages 215-232. 
Head, Keith, John Ries and Deborah Swenson (1995). "Agglomeration benefits and location choice: Evidence from Japanese manufacturing investments in the United States," Journal of International Economics 38 (3-4), 223-247.

Helpman, E. and P. Krugman (1985), Market Structure and International Trade. MIT Press.

Helpman, Elhanan (1984). "A Simple Theory of International Trade with Multinational Corporations," Journal of Political Economy 92(3): 451-471.

Helpman, Elhanan, Marc Melitz and Stephen Yeaple (2004). "Export Versus FDI with Heterogeneous Firms," American Economic Review, vol. 94(1), pages 300-316.

Irarrazabaly, Alfonso, Andreas Moxnes and Luca David Opromolla (2010)." The Margins of Multinational Production and the Role of Intra-firm Trade",

Javorcik, Beata Smarzynska (2004). "Does Foreign Direct Investment Increase the Productivity of Domestic Firms? In Search of Spillovers Through Backward Linkages," American Economic Review, vol. 94(3), pages 605-627.

Javorcik, Beata Smarzynska and Spatareanu, Mariana, (2008). "To share or not to share: Does local participation matter for spillovers from foreign direct investment?," Journal of Development Economics, vol. 85(1-2), pages 194-217.

Jones, Ronald, Kierzkowski, Henryk and Lurong, Chen, (2005). "What does evidence tell us about fragmentation and outsourcing?," International Review of Economics and Finance, vol. 14(3), pages 305-316.

Karolina Ekholm, Rikard Forslid and James R. Markusen, (2007). "Export-Platform Foreign Direct Investment," Journal of the European Economic Association, vol. 5(4), pages 776-795, 06

Kimura, Fukunari \& Takahashi, Yuya \& Hayakawa, Kazunobu, (2007). "Fragmentation and parts and components trade: Comparison between East Asia and Europe," The North American Journal of Economics and Finance, Elsevier, vol. 18(1), pages 23-40.

Kimura, Fukunari and Mitsuyo Ando (2005). "Two-dimensional fragmentation in East Asia: Conceptual framework and empirics," International Review of Economics and Finance, Elsevier, vol. 14(3), pages 317-348.

Krugman, Paul R and Anthony Venables (1995). "Globalization and the Inequality of Nations," The Quarterly Journal of Economics, vol. 110(4), pages 857-80.

Lipsey Robert and Merle Weiss (1981). "Foreign Production and Exports in Manufacturing Industries", The Review of Economics and Statistics, Vol. 63, No. 4, pp. 488-494.

Love, James H. (2003): Technology sourcing versus technology exploitation: an analysis of US foreign direct investment flows, Applied Economics, 35:15, 1667-1678

Markusen, J., Venables, A., 2000. The theory of endowment, intra-industry and multinational trade. Journal of International Economics 52, 209-234.

Markusen, James (1984). "Multinationals, Multi-Plant Economies, and the Gains from Trade," Journal of International Economics 16: 205-226.

Markusen, James R., and Keith E. Maskus. (2001). Multinational firms: Reconciling theory and evidence. In Topics in empirical international economics: A festschrift in honor of Robert E. Lipsey, ed. Magnus Blomstrom and Linda Goldberg, 71-95. Chicago: University of Chicago Press. 
Markusen, James R., and Keith E. Maskus. (2002). Discriminating among alternative theories of the multinational enterprise. Review of International Economics 10 (4): 694-707.

Melitz, Marc (2003). "The Impact of Trade on Intra-Industry Reallocations and Aggregate Industry Productivity," Econometrica, vol. 71(6), pages 1695-1725.

Navaretti, Giorgio Barba and Anthony J. Venables, (2004) Multinational Firms in the World Economy, Princeton University Press.

$\mathrm{Ng}$, Francis and Yeats, Alexander, (2003). "Major trade trends in East Asia : what are their implications for regional cooperation and growth," Policy Research Working Paper Series 3084, The World Bank..Siotis, Georges. (1999). 'Foreign Direct Investment Strategies and Firms' Capabilities', Journal of Economics and Management Strategy, Vol. 8, pp. 251-270.

Wagner, Joachim (2007). "Exports and Productivity: A Survey of the Evidence from Firmlevel Data," The World Economy, vol. 30(1), pages 60-82.

Yeaple, Stephen (2003a). "The complex integration strategies of multinationals and cross country dependencies in the structure of foreign direct investment", Journal of International Economics 60 (2), 293-314.

Yeaple, Stephen (2003b). "The Role of Skill Endowments in the Structure of U.S. Outward Foreign Direct Investment", Review of Economics and Statistics, 85(3), 726-734. 
Appendix: Classification of sectors

\section{Table 2: 6-way classification of sectors}

\section{Primary}

Forestry

Fisheries and Aquaculture

Metal mining

Construction

Food Manufacturing

Beverage Manufacturing

Prepared animal foods and organic fertilizers

Light manufacturing

Silk-reeling industry, spinning mills

Woven fabric mills, knit fabrics mills

Other fiber manufacturing

Apparel and other textile products

Chemical fibers

Lumber and wood products

Pulp, paper

Paper products

Chemicals

Chemical fertilizers

Inorganic products

Organic chemicals

Oil and fat products, soaps, synthetic detergents, surface-active agents and paints

Drugs and medicines

Cosmetics, toothpaste, and other make-up

goods

Other chemical and allied products

Petroleum refining

Other petroleum and coal products

Metal and metal products

Glass and its products

Cement and its products

Other ceramic, stone and clay products

Iron and Steel

Miscellaneous iron and steel

Smelting and refining of non-ferrous metals

Non-ferrous metals worked products

Fabricated constructional and architectural

metal products, including fabricated plate work and sheet metal work

Other fabricated metal products

\section{Machinery}

Metal working machinery

Special industry machinery

Office, service industry and household machines

Other general industry machinery and equipment

Industrial electromechanical apparatus manufacturing

Household electric appliances

Electronic equipment

Other electrical machinery equipment and supplies

Communication equipment and related products

Electronic data processing machines, digital and analog

computer, equipment and accessories

Electronic parts and devices

Motor vehicles

Auto parts and accessory manufacturing

Other transportation equipment

Optical instruments and lenses

Watches, clocks, clockwork-operated devices and parts

Other precision instruments and machinery

Furniture and fixtures

Printing and Allied Industry

Plastic products

Rubber products

Manufacturing industries, n.e.c.

\section{Services}

Electricity, Gas, Heat Supply and Water

Communications Industry

Broadcasting Industry

Information services

Internet supplementary services

Railway transport, road passenger transport, road

freight transport, water transport, air transport

Warehousing, services incidental to transport

Wholesale trade

Retail trade

Finance and insurance

Real estate

Restaurants

Lodging industry

Professional services

Goods rental and leasing

Advertising industry

Other services

Table version of figure 10 
Prepared animal foods and organic

$$
\text { fertilizers }
$$

Real estate

Lodging industry

Advertising industry

Restaurants

Broadcasting Industry

Information services

Electricity, Gas, Heat Supply and Water

Internet supplementary services

Construction

Paper products

Drugs and medicines

Beverage Manufacturing

Forestry

Watches, clocks, clockwork-operated devices and parts

Warehousing etc

Fabricated constructional and architectural metal products, including fabricated plate work and sheet metal work

Apparel and other textile products

Other petroleum and coal products

Retail trade

Communications Industry

Other chemical and allied products

Food Manufacturing

Miscellaneous iron and steel

Furniture and fixtures

Iron and Steel

Rubber products

Lumber and wood products

Other fabricated metal products

Other general industry machinery and equipment

Cement and its products

Cosmetics, toothpaste, and other makeup goods

Other ceramic, stone and clay products

Other fiber manufacturing

Motor vehicles

Plastic products

Glass and its products

Auto parts and accessory manufacturing

\begin{tabular}{|c|c|c|c|c|c|c|c|}
\hline $\begin{array}{l}\text { To } \\
\text { local }\end{array}$ & $\begin{array}{l}\text { To } \\
\text { Japan }\end{array}$ & $\begin{array}{l}\text { To } \\
\text { region }\end{array}$ & $\begin{array}{l}\text { To } \\
\text { RoW }\end{array}$ & $\begin{array}{l}\text { From } \\
\text { local }\end{array}$ & $\begin{array}{l}\text { From } \\
\text { Japan }\end{array}$ & $\begin{array}{l}\text { From } \\
\text { region }\end{array}$ & $\begin{array}{l}\text { From } \\
\text { RoW }\end{array}$ \\
\hline $100 \%$ & $0 \%$ & $0 \%$ & $0 \%$ & $100 \%$ & $0 \%$ & $0 \%$ & $0 \%$ \\
\hline $100 \%$ & $0 \%$ & $0 \%$ & $0 \%$ & $100 \%$ & $0 \%$ & $0 \%$ & $0 \%$ \\
\hline $97 \%$ & $3 \%$ & $0 \%$ & $0 \%$ & $100 \%$ & $0 \%$ & $0 \%$ & $0 \%$ \\
\hline $100 \%$ & $0 \%$ & $0 \%$ & $0 \%$ & $100 \%$ & $0 \%$ & $0 \%$ & $0 \%$ \\
\hline $100 \%$ & $0 \%$ & $0 \%$ & $0 \%$ & $99 \%$ & $1 \%$ & $0 \%$ & $0 \%$ \\
\hline $44 \%$ & $56 \%$ & $0 \%$ & $0 \%$ & $92 \%$ & $7 \%$ & $0 \%$ & $0 \%$ \\
\hline $82 \%$ & $18 \%$ & $0 \%$ & $0 \%$ & $43 \%$ & $57 \%$ & $0 \%$ & $0 \%$ \\
\hline $99 \%$ & $0 \%$ & $0 \%$ & $0 \%$ & $87 \%$ & $13 \%$ & $0 \%$ & $0 \%$ \\
\hline $94 \%$ & $6 \%$ & $0 \%$ & $0 \%$ & $98 \%$ & $0 \%$ & $1 \%$ & $0 \%$ \\
\hline $97 \%$ & $0 \%$ & $1 \%$ & $0 \%$ & $96 \%$ & $2 \%$ & $1 \%$ & $0 \%$ \\
\hline $97 \%$ & $2 \%$ & $0 \%$ & $0 \%$ & $89 \%$ & $6 \%$ & $1 \%$ & $2 \%$ \\
\hline $90 \%$ & $7 \%$ & $1 \%$ & $1 \%$ & $10 \%$ & $85 \%$ & $3 \%$ & $0 \%$ \\
\hline $91 \%$ & $0 \%$ & $2 \%$ & $2 \%$ & $97 \%$ & $2 \%$ & $0 \%$ & $0 \%$ \\
\hline $9 \%$ & $82 \%$ & $0 \%$ & $4 \%$ & $100 \%$ & $0 \%$ & $0 \%$ & $0 \%$ \\
\hline $39 \%$ & $53 \%$ & $3 \%$ & $1 \%$ & $46 \%$ & $53 \%$ & $1 \%$ & $0 \%$ \\
\hline $68 \%$ & $24 \%$ & $4 \%$ & $0 \%$ & $96 \%$ & $1 \%$ & $0 \%$ & $1 \%$ \\
\hline $82 \%$ & $14 \%$ & $2 \%$ & $0 \%$ & $86 \%$ & $7 \%$ & $2 \%$ & $2 \%$ \\
\hline $34 \%$ & $60 \%$ & $1 \%$ & $1 \%$ & $68 \%$ & $26 \%$ & $2 \%$ & $1 \%$ \\
\hline $95 \%$ & $1 \%$ & $2 \%$ & $0 \%$ & $69 \%$ & $22 \%$ & $0 \%$ & $4 \%$ \\
\hline $93 \%$ & $1 \%$ & $3 \%$ & $0 \%$ & $78 \%$ & $15 \%$ & $3 \%$ & $1 \%$ \\
\hline $97 \%$ & $1 \%$ & $1 \%$ & $0 \%$ & $5 \%$ & $82 \%$ & $0 \%$ & $7 \%$ \\
\hline $89 \%$ & $3 \%$ & $2 \%$ & $2 \%$ & $66 \%$ & $25 \%$ & $4 \%$ & $1 \%$ \\
\hline $71 \%$ & $21 \%$ & $2 \%$ & $2 \%$ & $90 \%$ & $2 \%$ & $2 \%$ & $2 \%$ \\
\hline $86 \%$ & $11 \%$ & $1 \%$ & $0 \%$ & $60 \%$ & $27 \%$ & $3 \%$ & $3 \%$ \\
\hline $49 \%$ & $47 \%$ & $1 \%$ & $1 \%$ & $74 \%$ & $12 \%$ & $6 \%$ & $1 \%$ \\
\hline $86 \%$ & $1 \%$ & $6 \%$ & $1 \%$ & $58 \%$ & $38 \%$ & $1 \%$ & $1 \%$ \\
\hline $75 \%$ & $13 \%$ & $4 \%$ & $2 \%$ & $65 \%$ & $30 \%$ & $2 \%$ & $1 \%$ \\
\hline $29 \%$ & $55 \%$ & $1 \%$ & $7 \%$ & $93 \%$ & $5 \%$ & $1 \%$ & $0 \%$ \\
\hline $78 \%$ & $10 \%$ & $5 \%$ & $1 \%$ & $52 \%$ & $41 \%$ & $2 \%$ & $1 \%$ \\
\hline $69 \%$ & $14 \%$ & $7 \%$ & $1 \%$ & $50 \%$ & $44 \%$ & $2 \%$ & $1 \%$ \\
\hline $98 \%$ & $0 \%$ & $0 \%$ & $1 \%$ & $76 \%$ & $2 \%$ & $0 \%$ & $11 \%$ \\
\hline $82 \%$ & $4 \%$ & $7 \%$ & $0 \%$ & $27 \%$ & $62 \%$ & $5 \%$ & $0 \%$ \\
\hline $71 \%$ & $18 \%$ & $4 \%$ & $1 \%$ & $60 \%$ & $25 \%$ & $2 \%$ & $5 \%$ \\
\hline $59 \%$ & $21 \%$ & $7 \%$ & $3 \%$ & $70 \%$ & $22 \%$ & $1 \%$ & $3 \%$ \\
\hline $76 \%$ & $6 \%$ & $6 \%$ & $3 \%$ & $58 \%$ & $29 \%$ & $5 \%$ & $1 \%$ \\
\hline $66 \%$ & $17 \%$ & $8 \%$ & $1 \%$ & $59 \%$ & $28 \%$ & $6 \%$ & $0 \%$ \\
\hline $71 \%$ & $9 \%$ & $9 \%$ & $0 \%$ & $21 \%$ & $67 \%$ & $4 \%$ & $1 \%$ \\
\hline $72 \%$ & $7 \%$ & $9 \%$ & $2 \%$ & $57 \%$ & $33 \%$ & $4 \%$ & $1 \%$ \\
\hline
\end{tabular}


Oil and fat products, soaps, synthetic detergents, surface-active agents and paints

Industrial electromechanical apparatus manufacturing

Inorganic products

Metal working machinery

Special industry machinery

Office, servce industry and household machines

Optical instruments and lenses

Smelting and refining of non-ferrous metals

Manufacturing industries, n.e.c.

Electronic data processing machines, digital and analog computer, equipment and accessories

Pulp, paper

Non-ferrous metals worked products

Organic chemicals

Communication equipment and related products

Other precision instruments and machinery

Electronic parts and devices

Household electric appliances

Metal mining

Goods rental and leasing

Other electrical machinery equipment and supplies

Professional services

Silk-reeling industry, spinning mills

Electronic equipment

Fisheries and Aquaculture

Woven fabric mills, knit fabrics mills

Wholesale trade

Chemical fertilizers

Chemical fibers

Printing and Allied Industry

Other services

Railway transport, road passenger transport, road freight transport, water transport, air transport

Petroleum refining

Finance and insurance

Other transportation equipment

\begin{tabular}{|c|c|c|c|c|c|c|c|}
\hline $78 \%$ & $3 \%$ & $6 \%$ & $3 \%$ & $55 \%$ & $26 \%$ & $6 \%$ & $3 \%$ \\
\hline $54 \%$ & $28 \%$ & $8 \%$ & $1 \%$ & $41 \%$ & $40 \%$ & $9 \%$ & $1 \%$ \\
\hline $75 \%$ & $6 \%$ & $2 \%$ & $8 \%$ & $49 \%$ & $33 \%$ & $4 \%$ & $5 \%$ \\
\hline $63 \%$ & $8 \%$ & $12 \%$ & $2 \%$ & $32 \%$ & $59 \%$ & $2 \%$ & $3 \%$ \\
\hline $63 \%$ & $3 \%$ & $3 \%$ & $14 \%$ & $40 \%$ & $49 \%$ & $4 \%$ & $1 \%$ \\
\hline $21 \%$ & $55 \%$ & $9 \%$ & $3 \%$ & $60 \%$ & $20 \%$ & $8 \%$ & $2 \%$ \\
\hline $57 \%$ & $16 \%$ & $13 \%$ & $1 \%$ & $8 \%$ & $72 \%$ & $10 \%$ & $0 \%$ \\
\hline $66 \%$ & $29 \%$ & $2 \%$ & $1 \%$ & $55 \%$ & $1 \%$ & $1 \%$ & $20 \%$ \\
\hline $60 \%$ & $16 \%$ & $8 \%$ & $4 \%$ & $46 \%$ & $29 \%$ & $7 \%$ & $5 \%$ \\
\hline $27 \%$ & $39 \%$ & $14 \%$ & $3 \%$ & $22 \%$ & $63 \%$ & $7 \%$ & $0 \%$ \\
\hline $36 \%$ & $28 \%$ & $4 \%$ & $14 \%$ & $75 \%$ & $11 \%$ & $0 \%$ & $6 \%$ \\
\hline $67 \%$ & $10 \%$ & $10 \%$ & $1 \%$ & $45 \%$ & $28 \%$ & $11 \%$ & $2 \%$ \\
\hline $61 \%$ & $9 \%$ & $11 \%$ & $4 \%$ & $64 \%$ & $17 \%$ & $8 \%$ & $1 \%$ \\
\hline $63 \%$ & $10 \%$ & $10 \%$ & $4 \%$ & $32 \%$ & $45 \%$ & $8 \%$ & $4 \%$ \\
\hline $43 \%$ & $15 \%$ & $15 \%$ & $6 \%$ & $39 \%$ & $51 \%$ & $4 \%$ & $1 \%$ \\
\hline $37 \%$ & $28 \%$ & $15 \%$ & $3 \%$ & $27 \%$ & $55 \%$ & $8 \%$ & $1 \%$ \\
\hline $53 \%$ & $13 \%$ & $10 \%$ & $7 \%$ & $45 \%$ & $33 \%$ & $10 \%$ & $1 \%$ \\
\hline $13 \%$ & $42 \%$ & $3 \%$ & $19 \%$ & $87 \%$ & $1 \%$ & $0 \%$ & $6 \%$ \\
\hline $41 \%$ & $0 \%$ & $30 \%$ & $0 \%$ & $98 \%$ & $2 \%$ & $0 \%$ & 0 \\
\hline $47 \%$ & $15 \%$ & $12 \%$ & $7 \%$ & $43 \%$ & $34 \%$ & $10 \%$ & $2 \%$ \\
\hline $77 \%$ & $12 \%$ & $0 \%$ & $5 \%$ & $30 \%$ & $19 \%$ & $26 \%$ & $0 \%$ \\
\hline $50 \%$ & $17 \%$ & $11 \%$ & $5 \%$ & $64 \%$ & $5 \%$ & $9 \%$ & $6 \%$ \\
\hline $21 \%$ & $23 \%$ & $5 \%$ & $23 \%$ & $59 \%$ & $32 \%$ & $4 \%$ & $1 \%$ \\
\hline $17 \%$ & $53 \%$ & $8 \%$ & $8 \%$ & $50 \%$ & $12 \%$ & $10 \%$ & $9 \%$ \\
\hline $34 \%$ & $25 \%$ & $10 \%$ & $11 \%$ & $55 \%$ & $16 \%$ & $9 \%$ & $6 \%$ \\
\hline $55 \%$ & $16 \%$ & $11 \%$ & $4 \%$ & $24 \%$ & $32 \%$ & $11 \%$ & $11 \%$ \\
\hline $80 \%$ & $6 \%$ & $7 \%$ & $0 \%$ & $21 \%$ & $19 \%$ & $12 \%$ & $18 \%$ \\
\hline $40 \%$ & $8 \%$ & $19 \%$ & $8 \%$ & $48 \%$ & $27 \%$ & $5 \%$ & $8 \%$ \\
\hline $59 \%$ & $3 \%$ & $9 \%$ & $10 \%$ & $35 \%$ & $22 \%$ & $11 \%$ & $10 \%$ \\
\hline $42 \%$ & $19 \%$ & $13 \%$ & $6 \%$ & $43 \%$ & $15 \%$ & $13 \%$ & \\
\hline $14 \%$ & $21 \%$ & $28 \%$ & $5 \%$ & $16 \%$ & $59 \%$ & $12 \%$ & \\
\hline $18 \%$ & $80 \%$ & $1 \%$ & $1 \%$ & $8 \%$ & $3 \%$ & $43 \%$ & $1 \%$ \\
\hline $65 \%$ & $0 \%$ & $13 \%$ & $4 \%$ & $13 \%$ & $0 \%$ & $34 \%$ & $10 \%$ \\
\hline $22 \%$ & $6 \%$ & $31 \%$ & $5 \%$ & $17 \%$ & $25 \%$ & $16 \%$ & \\
\hline
\end{tabular}

